Published in final edited form as:

Cochrane Database Syst Rev. ; 3: CD008244. doi:10.1002/14651858.CD008244.pub2.

\title{
Milnacipran for neuropathic pain and fibromyalgia in adults
}

\author{
Sheena Derry ${ }^{1}$, Dipender Gill ${ }^{1}$, Tudor Phillips ${ }^{1}$, and R Andrew Moore ${ }^{1}$ \\ ${ }^{1}$ Pain Research and Nuffield Department of Clinical Neurosciences (Nuffield Division of \\ Anaesthetics), University of Oxford, Oxford, UK
}

\begin{abstract}
Background-Milnacipran is a serotonin-norepinephrine reuptake inhibitor (SNRI) that is sometimes used to treat chronic neuropathic pain and fibromyalgia.

Objectives-To evaluate the analgesic efficacy and adverse effects of milnacipran in the management of chronic neuropathic pain or fibromyalgia.
\end{abstract}

Search methods-We searched CENTRAL, MEDLINE, and EMBASE to 4th of January 2012, together with reference lists of retrieved papers and reviews.

Selection criteria-We included randomised, double-blind studies of eight weeks duration or longer, comparing milnacipran with placebo or another active treatment in chronic neuropathic pain or fibromyalgia.

Data collection and analysis-We extracted efficacy and adverse event data, and two study authors examined issues of study quality independently.

Main results—Five studies (4138 participants) were included, all of which were placebocontrolled, involved participants with fibromyalgia, and used titration to a target dose of $100 \mathrm{mg}$ or $200 \mathrm{mg}$ milnacipran. There were no other active comparators or studies in other neuropathic pain conditions. Study quality was generally good, although the imputation method used in analyses of the primary outcomes could overestimate treatment effect.

Both doses of milnacipran provided moderate levels of pain relief to about $40 \%$ of those treated, compared to $30 \%$ with placebo, giving a number needed to treat of 8 to 10 . Adverse events were common in both milnacipran $(87 \%)$ and placebo $(78 \%)$ groups, but serious adverse events $(<2 \%)$ did not differ between groups. Nausea and constipation were the most common events showing

Copyright @ 2012 The Cochrane Collaboration. Published by John Wiley \& Sons, Ltd

Contact address: Sheena Derry, Pain Research and Nuffield Department of Clinical Neurosciences (Nuffield Division of Anaesthetics), University of Oxford, Churchill Hospital, Oxford, Oxfordshire, OX3 7LE, UK. sheena.derry@ pru.ox.ac.uk.

CONTRIBUTIONS OF AUTHORS RAM and SD wrote the protocol. DG and TP carried out searches and assessed studies for inclusion. SD, DG, and TP extracted data and carried out analyses. RAM acted as arbitrator. All authors were involved in writing the review. RAM will be responsible for updating the review.

Editorial group: Cochrane Pain, Palliative and Supportive Care Group.

Publication status and date: New, published in Issue 3, 2012.

Review content assessed as up-to-date: 4 January 2012.

DECLARATIONS OF INTEREST SD and RAM have received research support from charities, government, and industry sources at various times. RAM has consulted for various pharmaceutical companies and received lecture fees from pharmaceutical companies related to analgesics and other healthcare interventions. DG and TP have no interests to declare. No company with any interest in milnacipran had any involvement in the production of this review. 
the greatest difference between groups (number needed to treat for an additional harmful outcome of 7 and 13 respectively, compared with placebo).

Withdrawals for any reason were more common with milnacipran than placebo, and more common with $200 \mathrm{mg}$ than $100 \mathrm{mg}$ (NNH of 23 and 8.8 respectively, compared with placebo). This was largely driven by adverse event withdrawals, where the NNH compared with placebo was 14 for $100 \mathrm{mg}$, and 7.0 for $200 \mathrm{mg}$ ). Withdrawals due to lack of efficacy were more common with milnacipran than placebo but did not differ between doses (number needed to treat to prevent an additional unwanted outcome of 45 and 41 respectively).

Authors' conclusions-The evidence available indicates that milnacipran $100 \mathrm{mg}$ or $200 \mathrm{mg}$ is effective for a minority in the treatment of pain due to fibromyalgia, providing moderate levels of pain relief (at least $30 \%$ ) to about $40 \%$ of participants, compared with about $30 \%$ with placebo. There were insufficient data to assess substantial levels of pain relief (at least 50\%), and the use of last observation carried forward imputation may overestimate drug efficacy. Milnacipran is associated with increased adverse events and adverse event withdrawals, which were significantly greater for the higher dose. There were no data for the use of milnacipran for other chronic neuropathic pain conditions.

\section{Medical Subject Headings (MeSH)}

Analgesics [adverse effects; *therapeutic use]; Chronic Disease; Cyclopropanes [adverse effects; *therapeutic use]; Fibromyalgia [*drug therapy]; Neuralgia [*drug therapy]; Serotonin Uptake Inhibitors [adverse effects; *therapeutic use]

\section{MeSH check words}

Adult; Humans

\section{BACKGROUND}

\section{Description of the condition}

Neuropathic pain, unlike nociceptive pain such as gout and other forms of arthritis, is caused by nerve damage, often accompanied by changes in the central nervous system (CNS). The new (2011) definition of neuropathic pain is "pain caused by a lesion or disease of the somatosensory system" (Jensen 2011). Fibromyalgia is a complex pain syndrome, defined as widespread pain for longer than three months with pain on palpation at 11 or more of 18 specified tender points (Wolfe 1990), and frequently associated with other symptoms such as poor sleep, fatigue, and depression. More recently, a definition of fibromyalgia has been proposed based on symptom severity and the presence of widespread pain (Wolfe 2010). The cause or causes of fibromyalgia are not well understood, but it has features in common with neuropathic pain, including changes in the CNS. Many people with these conditions are significantly disabled with moderate or severe pain for many years. Conventional analgesics are usually not effective, although opioids may be in some individuals. Others may derive some benefit from a topical lidocaine patch or topical capsaicin. Treatment is more usually by unconventional analgesics such as antidepressants or antiepileptics. 
Data for the incidence of neuropathic pain are difficult to obtain. However, a systematic review of prevalence and incidence in the Oxford Region of the UK indicates prevalence rates per 100,000 of 34 for postherpetic neuralgia, 400 for diabetic neuropathy and trigeminal neuropathy, and 2000 for fibromyalgia (McQuay 2007). Different estimates in the UK indicate incidences per 100,000 person-years observation of 40 (95\% confidence interval (CI) 39 to 41) for post-herpetic neuralgia, 27 (26 to 27) for trigeminal neuralgia, 1 (1 to 2) for phantom limb pain, and 15 (15 to 16) for painful diabetic neuropathy, with rates decreasing in recent years for phantom limb pain and post-herpetic neuralgia and increasing for painful diabetic neuropathy (Hall 2006). The prevalence of neuropathic pain in Austria was reported as being 3.3\% (Gustorff 2008).

Neuropathic pain and fibromyalgia are commonly difficult to treat effectively, with only a minority of individuals experiencing a clinically relevant benefit from any one intervention. A multidisciplinary approach is now advocated, with physical or cognitive, or both, therapies being combined with pharmacological interventions. Recent research has indicated that adequate treatment of chronic neuropathic pain results in improvements in associated symptoms, including sleep and psychological symptoms (Hoffman 2010; Moore 2010c), and in the ability to work (Straube 2011).

\section{Description of the intervention}

Milnacipran (trade names Ixel, Savella) is a serotonin-norepinephrine reuptake inhibitor (SNRI), used to treat depression and chronic pain. It is licensed for different indications in different countries and is a relatively new therapy.

\section{How the intervention might work}

5-hydroxytryptamine (5HT or serotonin) and norepinephrine (NE) are involved in the modulation of endogenous analgesic mechanisms via descending inhibitory pain pathways in the brain and the spinal cord (Suzuki 2004). Disinhibition and imbalance of 5HT and NE in endogenous pain inhibitory pathways could contribute to persistent pain. An increase in 5HT and NE may increase inhibition of painful signals, improving pain relief, but the exact mechanism of action is not fully understood.

\section{Why it is important to do this review}

Milnacipran is a recent addition to the pharmacological interventions available to treat chronic neuropathic pain and fibromyalgia. There is no systematic review of its efficacy in these conditions. It is important to establish its efficacy compared with placebo or other active interventions to understand its place amongst the available treatment options.

There have been several recent changes in how efficacy of conventional and unconventional treatments is assessed in chronic painful conditions. The outcomes are now better defined, particularly with new criteria of what constitutes moderate or substantial benefit (Dworkin 2008); older trials may only report participants with "any improvement". Newer trials tend to be larger, avoiding problems from the random play of chance. Newer trials also tend to be longer, up to 12 weeks, and longer trials provide a more rigorous and valid assessment of efficacy in chronic conditions. New standards have evolved for assessing efficacy in 
neuropathic pain, and we are now applying stricter criteria for inclusion of trials and assessment of outcomes, and are more aware of problems that may affect our overall assessment (Moore 2010a; Moore 2011). To summarise some of the recent insights that make a new review necessary, over and above including more trials:

1. Pain results tend to have a U-shaped distribution rather than a bell-shaped distribution (see Moore 2005 for acute pain). This is true in acute pain and arthritis (Moore 2010b) as well as in fibromyalgia; in all cases average results usually describe the experience of almost no-one in the trial. Data expressed as averages are potentially misleading, unless this can be proven to be suitable.

2. As a consequence, we have to depend on dichotomous results (the individual either has or does not have the outcome) usually from pain changes or patient global assessments. The IMMPACT group has helped with their definitions of minimal, moderate, and substantial improvement (Dworkin 2008). In arthritis, trials shorter than 12 weeks, and especially those shorter than eight weeks, overestimate the effect of treatment (Moore 2010b); the effect is particularly strong for less effective analgesics, and this may also be relevant in neuropathic-type pain.

3. The proportion with at least moderate benefit can be small, even with an effective medicine, falling from $60 \%$ with an effective medicine in arthritis, to $30 \%$ in fibromyalgia (Moore 2010b; Straube 2008; Sultan 2008). A Cochrane review of pregabalin in neuropathic pain and fibromyalgia demonstrated different response rates for different types of chronic pain (higher in diabetic neuropathy and postherpetic neuralgia and lower in central pain and fibromyalgia) (Moore 2009). This indicates that different neuropathic pain conditions should be treated separately from one another, and that pooling should not be done unless there are good grounds for doing so.

4. Imputation methods like last observation carried forward, used when participants withdraw from clinical trials, can overstate drug efficacy especially when adverse event withdrawals with drug are greater than those with placebo (Moore 2011).

5. Finally, presently unpublished individual patient analyses indicate that patients who get good pain relief (moderate or better) have major benefits in many other outcomes, affecting quality of life in a significant way.

This Cochrane review therefore assesses evidence in ways that make both statistical and clinical sense. Trials included and analysed have to meet a minimum of reporting quality (blinding, randomisation), validity (duration, dose and timing, diagnosis, outcomes, etc), and size (ideally a minimum of 500+ participants in a comparison in which numbers needed to treat (NNTs) are four or above (Moore 1998)). This does set high standards, and marks a departure from how reviews have been conducted previously.

\section{OBJECTIVES}

1. To assess the analgesic efficacy of milnacipran for chronic neuropathic pain and fibromyalgia. 
2. To assess the adverse events associated with the clinical use of milnacipran for chronic neuropathic pain and fibromyalgia.

\section{METHODS}

\section{Criteria for considering studies for this review}

Types of studies-We included studies if they were randomised controlled trials (RCTs) with double-blind assessment of outcomes, reported after eight weeks of treatment or longer. Full journal publication was required, with the exception of extended abstracts of otherwise unpublished clinical trials. Short abstracts (usually meeting reports) were not included. We excluded non-randomised studies, studies of experimental pain, case reports, and clinical observations.

Types of participants-We included studies enrolling adult participants aged 18 years and above, with one or more central or peripheral chronic neuropathic pain conditions including:

- painful diabetic neuropathy;

- post-herpetic neuralgia;

- trigeminal neuralgia;

- phantom limb pain;

- postoperative or traumatic neuropathic pain;

- complex regional pain syndrome;

- cancer-related neuropathy;

- Guillain Barré;

- $\quad$ HIV-neuropathy;

- $\quad$ spinal cord injury;

- fibromyalgia.

We planned to include studies of participants with more than one type of neuropathic pain and analyse results according to the primary condition.

Types of interventions-Milnacipran in any dose, by any route, administered for the relief of neuropathic pain or fibromyalgia, and compared to placebo, no intervention or any other active comparator. We excluded studies using milnacipran to treat pain resulting from the use of other drugs.

Types of outcome measures-We expected that a variety of outcome measures would be used in the studies, based on standard subjective scales for pain intensity or pain relief, or both. Acceptable scales for measurement of pain intensity were $100 \mathrm{~mm}$ visual analogue scale (VAS) (no pain to worst pain imaginable) or four-point categorical scale (none, mild, moderate, severe), and for pain relief were $100 \mathrm{~mm}$ VAS (no relief to complete relief) or 
five-point categorical scale (none, a little, some, a lot, complete, or similar wording). We paid particular attention to IMMPACT definitions for moderate and substantial benefit in chronic pain studies (Dworkin 2008). These are defined as at least 30\% pain relief over baseline (moderate), at least 50\% pain relief over baseline (substantial), much or very much improved on Patient Global Impression of Change (PGIC) (moderate), and very much improved on PGIC (substantial). These outcomes are different from those set out in an earlier review of antidepressants for neuropathic pain (Saarto 2007), concentrating on dichotomous outcomes where pain responses are not normally distributed.

\section{Primary outcomes}

1. Patient reported pain relief of $30 \%$ or greater.

2. Patient reported pain relief of $50 \%$ or greater.

3. Patient reported global impression of clinical change (PGIC) much or very much improved.

4. Patient reported global impression of clinical change (PGIC) very much improved.

\section{Secondary outcomes}

1. Any pain-related outcome indicating some improvement.

2. Withdrawals due to lack of efficacy.

3. Participants experiencing any adverse event.

4. Participants experiencing any serious adverse event.

5. Withdrawals due to adverse events.

6. Specific adverse events, particularly somnolence and dizziness.

\section{Search methods for identification of studies}

Electronic searches-We searched the following databases:

- the Cochrane Central Register of Controlled Trials (CENTRAL) (to 4 January 2012);

- MEDLINE (via Ovid) (to 4 January 2012);

- $\operatorname{EMBASE}$ (via Ovid) (to 4 January 2012).

See Appendix 1 for the MEDLINE search strategy, Appendix 2 for the EMBASE search strategy, and Appendix 3 for the CENTRAL search strategy.

There was no language restriction.

Searching other resources-We searched reference lists of retrieved articles and reviews for any additional studies, and asked the manufacturer of milnacipran to provide additional unpublished dichotomous outcome data to complement published reports. We also searched the database ClinicalTrials.gov. 


\section{Data collection and analysis}

Selection of studies-Two review authors read the abstract of each study identified by the search, eliminated studies that clearly did not satisfy the inclusion criteria, and obtained full copies of the remaining studies. The same authors then independently read these studies to determine eligibility; any disagreements or uncertainty were settled by discussion, with a third author if necessary. Studies were not anonymised in any way before assessment.

Data extraction and management-Two review authors extracted data using a standard form and agreed data before entry into RevMan 5 (RevMan 2011) or any other analysis method. Data extracted included information about the pain condition and number of participants treated, drug and dosing regimen, study design (placebo or active control), study duration and follow-up, analgesic outcome measures and results, withdrawals, and adverse events (participants experiencing any adverse event, or a serious adverse event).

Assessment of risk of bias in included studies-We used the 'Risk of bias' tool available in RevMan 5 to report on sequence generation, allocation concealment, blinding, and other risks such as reporting of dropouts.

Measures of treatment effect-We used dichotomous data to calculate relative risk (RR) with 95\% confidence intervals (CI) using a fixed-effect model unless we found significant statistical heterogeneity (see below). We calculated numbers needed to treat to benefit (NNTs) as the reciprocal of the absolute risk reduction (McQuay 1998). For unwanted effects, the NNT becomes the number needed to treat to harm (NNH), and is calculated in the same manner. Where the unwanted effect is less common with treatment than control, we used the term number needed to treat to prevent (NNTp).

We did not use continuous data because it is inappropriate where there is an underlying skewed distribution, as is usually the case with analgesic response.

Unit of analysis issues-We accepted randomisation to individual patient only.

Dealing with missing data-We used intention-to-treat (ITT) analysis, where the ITT population consisted of participants who were randomised, took the assigned study medication, and provided at least one post-baseline assessment. We assigned missing participants zero improvement.

Assessment of heterogeneity-We dealt with clinical heterogeneity by combining studies that examine similar conditions, while we assessed statistical heterogeneity visually (L'Abbé 1987) and with the use of the $\mathrm{I}^{2}$ statistic.

Assessment of reporting biases-The aim of this review is to use dichotomous data of known utility (Moore 2010b). The review does not depend on what authors of the original studies chose to report or not.

Data synthesis-We carried out meta-analysis using a fixed-effect model. 
Subgroup analysis and investigation of heterogeneity-We planned subgroup analysis for:

- dose of milnacipran;

- different painful conditions.

Sensitivity analysis-We planned no sensitivity analyses, because the evidence base was known to be too small to allow reliable analysis. Results from neuropathic pain of different origins would not be pooled.

\section{RESULTS}

\section{Description of studies}

See: Characteristics of included studies; Characteristics of excluded studies; Characteristics of ongoing studies.

Results of the search-The searches yielded eight potentially relevant studies, all of which used milnacipran to treat fibromyalgia. We found no relevant studies for any type of chronic neuropathic pain. The manufacturers of milnacipran did not provide any additional information to that retrieved in our searches.

Included studies-Five studies fulfilled the inclusion criteria. The vast majority of participants were women (93\% to 97\%) and white (84\% to 93\%), and the mean age was 47 to 50 years. All had fibromyalgia diagnosed according to American College of Rheumatology (ACR) 1990 criteria, and baseline pain of 60/100 on a visual analogue scale, or 10/20 on the Gracely scale. Full details are in the Characteristics of included studies table.

Arnold 2010: one to four weeks screening and washout, four to six weeks flexible dose titration, and 12 weeks of stable dose $100 \mathrm{mg} /$ day (50 mg twice daily) milnacipran or placebo.

Branco 2010: similar screening, washout, dose escalation, and stable dose except that the stable target dose was $200 \mathrm{mg} /$ day milnacipran (100 mg twice daily), or placebo. This study also included a nine-day period of down-titration, with two-week follow-up.Clauw 2008: similar screening, washout, dose escalation, and stable dose except dose escalation was carried out over three weeks, then 12 weeks at a stable dose of either $100 \mathrm{mg} / \mathrm{day}(50 \mathrm{mg}$ twice daily) or $200 \mathrm{mg} /$ day (100 mg twice daily) milnacipran, or placebo.Mease 2009: similar in structure with three weeks of baseline measurement, followed by 24 weeks at a stable dose of $100 \mathrm{mg} /$ day milnacipran $(50 \mathrm{mg}$ twice daily) or $200 \mathrm{mg} /$ day (100 mg twice daily) milnacipran, or placebo (ratio 1:1:2 respectively).

Vitton 2004: similar study to the others, with two weeks of baseline measurement, four weeks dose titration, and eight weeks stable at a dose of $200 \mathrm{mg} /$ day milnacipran (once daily), $200 \mathrm{mg} /$ day milnacipran (100 $\mathrm{mg}$ twice daily), or placebo (ratio 3:3:2 respectively).

A total of 1141 participants received milnacipran $100 \mathrm{mg}, 1383$ received milnacipran 200 $\mathrm{mg}$, and 1614 received placebo. No study used a different active comparator. All studies 
used electronic patient experience diaries (PED) to collect data, and were carried out over 8 to 24 weeks.

Excluded studies-We excluded three studies (Branco 2011; Goldenberg 2010;NCT00797797). Reasons for exclusion are in the Characteristics of excluded studies table.

\section{Risk of bias in included studies}

Allocation-Arnold 2010 and Clauw 2008 adequately described the methods used to ensure that allocation of participants to treatment groups was concealed. The remaining three studies (Branco 2010; Mease 2009; Vitton 2004) did not report the method used.

Blinding-All studies were described as double-blind, but Mease 2009 did not describe the methods used to ensure that participants and interacting investigators were unable to differentiate between the treatment and control tablets. The other four studies provided adequate information.

Incomplete outcome data-All five studies used last observation carried forward to input data for participants who withdrew for any reason in analyses of individual pain outcomes. The three studies (Arnold 2010; Branco 2010; Clauw 2008) that reported composite outcomes performed baseline observation carried forward (any participant who withdrew for any reason was considered a non-responder) for these analyses.

Selective reporting-All five studies (Arnold 2010; Branco 2010; Clauw 2008; Mease 2009; Vitton 2004) reported the outcomes specified in the methods.

Other potential sources of bias-Vitton 2004 included 51 patients in each arm and thus treatment group size was an issue. Studies with small group sizes tend to overestimate efficacy (Kjaergard 2001; Nuesch 2010).

See Figure 1 and Figure 2 for a graph and summary of the risk of bias in included studies.

\section{Effects of interventions}

Details of results in individual studies are in Appendix 4 (efficacy) and Appendix 5 (adverse events and withdrawals).

\section{Efficacy}

\section{Milnacipran 100 mg daily versus placebo}

Moderate benefit: Participants experiencing at least 30\% improvement from baseline pain intensity, or reporting a Patient Global Impression of Change (PGIC) of "much or very much improved" are considered to be experiencing moderate pain relief. Since the same studies reported both outcomes, the former is used preferentially, but both results are presented. 
Two studies (1825 participants) contributed data for 30\% pain relief (Arnold 2010; Clauw 2008).

- The proportion of participants with $30 \%$ pain relief with milnacipran $100 \mathrm{mg}$ was $41 \%$ (379/915, range $37 \%$ to $45 \%)$.

- The proportion of participants with $30 \%$ pain relief with placebo was $30 \%$ (271/910, range $29 \%$ to $31 \%$ ).

- The relative benefit of milnacipran compared with placebo was 1.4 (1.2 to 1.6), giving a number needed to treat to benefit (NNT) of 8.6 (6.3 to 14) for moderate pain relief (Figure 3; Analysis 1.1).

Using data for participants reporting PGIC gave a relative benefit of 1.5 (1.3 to 1.7), and a NNT of 7.6 (5.7 to 11) for moderate pain relief (Analysis 1.2).

Substantial benefit: Only one study reported at least 50\% improvement from baseline pain intensity, which is considered equivalent to substantial benefit (Arnold 2010); 28\% (170/613) of participants treated with milnacipran $100 \mathrm{mg}$, and 18\% (96/537) of those treated with placebo experienced this outcome.

Data for 30\% and 50\% pain relief and PGIC were reported using last observation carried forward, an imputation method that has been shown to overestimate efficacy in circumstances where there is an imbalance of adverse events withdrawals in test and comparator treatment arms.

Some studies also reported composite responder outcomes using baseline observation carried forward (participants who withdrew were considered to be non-responders and have no pain relief at end of trial). Composite outcomes are more difficult to achieve, since two or more criteria must be satisfied.

Composite 1: 30\% pain relief + PGIC much or very much improved: Three studies (2272 participants) contributed data for the two-part composite outcome (Arnold 2010; Clauw 2008; Mease 2009).

- The proportion of participants achieving Composite 1 with milnacipran $100 \mathrm{mg}$ was $27 \%$ (303/1139, range $23 \%$ to $29 \%)$.

- The proportion of participants achieving Composite 1 with placebo was $18 \%$ (202/1133, range $18 \%$ to $19 \%)$.

- The relative benefit of milnacipran compared with placebo was 1.5 (1.3 to 1.7), giving a NNT of 11 (8.2 to 19) for 30\% pain relief + PGIC much or very much improved (Analysis 1.3).

Three studies (2272 participants) contributed data for the three-part composite outcome (Arnold 2010; Clauw 2008; Mease 2009). 


\section{Composite 2: $30 \%$ pain relief + PGIC much or very much improved + 6-point improvement in physical function}

- The proportion of participants achieving Composite 2 with milnacipran $100 \mathrm{mg}$ was $18 \%$ (206/1139, range $15 \%$ to $20 \%)$.

- The proportion of participants achieving Composite 2 with placebo was $10 \%$ (118/1133, range $9 \%$ to $12 \%)$.

- The relative benefit of milnacipran compared with placebo was 1.7 (1.4 to 2.1), giving a NNT of 13 (9.5 to 21) for 30\% pain relief + PGIC much or very much improved + 6-point improvement in physical function (Analysis 1.4).

Milnacipran 200 mg daily versus placebo: Vitton 2004 included two groups of participants receiving milnacipran $200 \mathrm{mg}$ daily, one as a divided dose (100 $\mathrm{mg}$ twice daily), and the other as a single dose (200 $\mathrm{mg}$ once daily). Since these groups gave numerically very similar responses and individually were too small (51 and 46 participants respectively) to show a difference reliably, we have combined them for analyses in this review.

Moderate benefit: Three studies (1798 participants) contributed data for 30\% pain relief (Branco 2010; Clauw 2008; Vitton 2004).

- The proportion of participants with $30 \%$ pain relief with milnacipran $200 \mathrm{mg}$ was $39 \%$ (361/923, range $35 \%$ to $40 \%)$.

- The proportion of participants with $30 \%$ pain relief with placebo was $29 \%$ (255/875, range $21 \%$ to $30 \%)$.

- The relative benefit of milnacipran compared with placebo was 1.4 (1.2 to 1.5), giving a NNT of 10 (7.0 to 18) for moderate pain relief (Analysis 2.1).

Using data for participants reporting PGIC gave a relative benefit of 1.6 (1.4 to 1.9) and a NNT of 6.1 (4.8 to 8.2) for moderate pain relief (Analysis 2.2).

Substantial benefit: Only one study (two treatment arms) reported at least 50\% improvement from baseline pain intensity, which is considered equivalent to substantial benefit (Vitton 2004); 29\% (15/51) of participants treated with milnacipran $2 \times 100 \mathrm{mg}$, $26 \%$ of those treated with $1 \times 200 \mathrm{mg}$, and $14 \%$ (4/28) of those treated with placebo experienced this outcome.

Composite 1: 30\% pain relief + PGIC much or very much improved: Three studies (2337 participants) contributed data for the two-part composite outcome (Branco 2010; Clauw 2008; Mease 2009).

- The proportion of participants achieving Composite 1 with milnacipran $200 \mathrm{mg}$ was $25 \%$ (320/1267, range $23 \%$ to $27 \%)$.

- The proportion of participants achieving Composite 1 with placebo was $16 \%$ (170/1070, range $13 \%$ to $19 \%)$. 
- The relative benefit of milnacipran compared with placebo was 1.6 (1.3 to 1.8 ), giving a NNT of 11 (7.9 to 16) for 30\% pain relief + PGIC much or very much improved (Analysis 2.3).

Composite 2: 30\% pain relief + PGIC much or very much improved + 6-point improvement in physical function: Two studies (1461 participants) contributed data for the three-part composite outcome (Clauw 2008; Mease 2009).

- The proportion of participants achieving Composite 2 with milnacipran $200 \mathrm{mg}$ was $17 \%(141 / 837$, range $14 \%$ to $19 \%)$.

- The proportion of participants achieving Composite 2 with placebo was $10 \%$ (62/624, range $9 \%$ to $12 \%)$.

- The relative benefit of milnacipran compared with placebo was 1.6 (1.2 to 2.1), giving a NNT of 14 (9.7 to 29) for 30\% pain relief + PGIC much or very much improved + 6-point improvement in physical function (Analysis 2.4).

Summary of results A: Efficacy outcomes with different doses of milnacipran in fibromyalgia

\begin{tabular}{|c|c|c|c|c|c|c|}
\hline & Number & & Per cent with & utcome & & \\
\hline Outcome - daily dose & Studies & Participants & Milnacipran & Placebo & $\begin{array}{l}\text { Relative benefit } \\
(95 \% \text { CI })\end{array}$ & $\begin{array}{l}\text { NNT } \\
(\mathbf{9 5 \%} \text { CI })\end{array}$ \\
\hline \multicolumn{7}{|c|}{ Moderate response: $\geq \mathbf{3 0} \%$ pain relief } \\
\hline $100 \mathrm{mg}$ & 2 & 1825 & 41 & 30 & $1.4(1.2$ to 1.6$)$ & $8.6(6.3$ to 14$)$ \\
\hline $200 \mathrm{mg}$ & 3 & 1798 & 39 & 29 & $1.4(1.2$ to 1.5$)$ & $10(7.0$ to 18$)$ \\
\hline \multicolumn{7}{|c|}{ Moderate response: PGIC much or very much improved } \\
\hline $100 \mathrm{mg}$ & 2 & 1825 & 39 & 25 & $1.5(1.3$ to 1.7$)$ & $7.6(5.7$ to 11$)$ \\
\hline $200 \mathrm{mg}$ & 3 & 1798 & 40 & 23 & $1.6(1.4$ to 1.9$)$ & $6.1(4.8$ to 8.2$)$ \\
\hline \multicolumn{7}{|c|}{ Substantial response: $\geq \mathbf{5 0 \%}$ pain relief } \\
\hline $100 \mathrm{mg}$ & 1 & 1025 & 28 & 18 & not calculated & not calculated \\
\hline $200 \mathrm{mg}$ & 1 & 125 & 28 & 14 & not calculated & not calculated \\
\hline \multicolumn{7}{|l|}{ Composite outcome 1} \\
\hline $100 \mathrm{mg}$ & 3 & 2272 & 27 & 18 & $1.5(1.3$ to 1.7$)$ & $11(8.2$ to 19$)$ \\
\hline $200 \mathrm{mg}$ & 3 & 2337 & 25 & 16 & $1.6(1.3$ to 1.8$)$ & $11(7.9$ to 16$)$ \\
\hline \multicolumn{7}{|l|}{ Composite outcome 2} \\
\hline $100 \mathrm{mg}$ & 3 & 2272 & 18 & 10 & $1.7(1.4$ to 2.1$)$ & $13(9.5$ to 21$)$ \\
\hline $200 \mathrm{mg}$ & 2 & 1461 & 17 & 10 & $1.6(1.2$ to 2.1$)$ & $14(9.7$ to 29$)$ \\
\hline \multicolumn{7}{|c|}{ Composite 1: $\geq 30 \%$ improvement from baseline PI + PGIC much or very much improved } \\
\hline \multicolumn{7}{|c|}{$\begin{array}{l}\text { Composite } 2: \geq 30 \% \text { improvement from baseline PI + PGIC much or very much improved }+\geq 6 \text {-point improvement in } \\
\text { physical function }\end{array}$} \\
\hline
\end{tabular}




\section{Adverse events}

Participants with any adverse event: All studies provided some information on participants experiencing adverse events over the study period, which was collected from spontaneous reports, and clinical observation and evaluation.Vitton 2004 did not provide data suitable for pooled analysis. Three studies (Arnold 2010; Clauw 2008; Mease 2009) provided data on the number of participants experiencing one or more adverse events with milnacipran 100 $\mathrm{mg}$ (2272 participants) and $200 \mathrm{mg}$ (2338 participants). The majority of individuals with both milnacipran and placebo reported at least one adverse event over the period, with no difference between the two doses tested.

For $100 \mathrm{mg}$ milnacipran versus placebo, $86 \%$ of those with active treatment and $78 \%$ with placebo had an event, and for milnacipran $200 \mathrm{mg}$ versus placebo, $87 \%$ of those with active treatment and 78\% with placebo had an event, giving a relative risk of 1.1 (1.06 to 1.14) for both doses, and a number needed to treat to harm (NNH) of 13 (9.3 to 22) for $100 \mathrm{mg}$, and 11 (8.2 to 16) for $200 \mathrm{mg}$ (Analysis 1.5; Analysis 2.5).

Serious adverse events: All studies reported on serious adverse events; $1.4 \%$ (16/1139) with milnacipran $100 \mathrm{mg}, 1.9 \%$ (26/1365) with milnacipran $200 \mathrm{mg}$, and 1.8\% (29/1607) with placebo. There were no significant difference between either dose of milnacipran and placebo (relative risk 0.9 ( 0.5 to 1.7$)$ and 0.9 (0.5 to 1.6)), or between the two doses of milnacipran (Analysis 1.6; Analysis 2.6).

Specific adverse events: Four studies (Arnold 2010; Branco 2010; Clauw 2008; Mease 2009) provided data for numbers of participants experiencing specific adverse events (Figure 4; Analysis 1.7; Analysis 2.7). Rates for each event were very similar for both doses of milnacipran, and are presented below for both doses combined, where there was a significant difference from placebo. Sinusitis, fatigue, and upper respiratory tract infection were no more common with milnacipran than placebo.

Summary of results B: Adverse events with different doses of milnacipran in fibromyalgia

\begin{tabular}{|c|c|c|c|c|c|c|}
\hline \multirow[b]{2}{*}{ Outcome - daily dose } & \multicolumn{2}{|c|}{ Number of } & \multicolumn{2}{|c|}{ Per cent with outcome } & \multirow[b]{2}{*}{$\begin{array}{l}\text { Relative risk } \\
(95 \% \text { CI) }\end{array}$} & \multirow[b]{2}{*}{$\begin{array}{l}\text { NNH } \\
(\mathbf{9 5 \%} \text { CI) }\end{array}$} \\
\hline & Studies & Participants & Milnacipran & Placebo & & \\
\hline \multicolumn{7}{|l|}{ Any adverse event } \\
\hline $100 \mathrm{mg}$ & 3 & 2272 & 86 & 78 & $\begin{array}{l}1.1 \text { (1.06 to } \\
1.14 \text { ) }\end{array}$ & 13 (9.3 to 22$)$ \\
\hline $200 \mathrm{mg}$ & 3 & 2338 & 87 & 78 & $\begin{array}{l}1.1(1.06 \text { to } \\
1.14)\end{array}$ & 11 (8.2 to 16$)$ \\
\hline \multicolumn{7}{|l|}{ Serious adverse event } \\
\hline $100 \mathrm{mg}$ & 5 & 2746 & 1.4 & 1.8 & $\begin{array}{l}0.9(0.5 \text { to } \\
1.7)\end{array}$ & not calculated \\
\hline $200 \mathrm{mg}$ & 5 & 2972 & 1.9 & 1.8 & $\begin{array}{l}0.9(0.5 \text { to } \\
1.6)\end{array}$ & not calculated \\
\hline
\end{tabular}




\begin{tabular}{|c|c|c|c|c|c|c|}
\hline & Number & & Per cent with & utcome & & \\
\hline Outcome - daily dose & Studies & Participants & Milnacipran & Placebo & $\begin{array}{l}\text { Relative risk } \\
\text { (95\% CI) }\end{array}$ & $\begin{array}{l}\text { NNH } \\
(95 \% \text { CI) }\end{array}$ \\
\hline Nausea & 4 & 3986 & 35 & 18 & $\begin{array}{l}1.9 \text { (1.7 to } \\
2.1)\end{array}$ & 7.0 (6 to 9$)$ \\
\hline Headache & 4 & 3986 & 17 & 14 & $\begin{array}{l}1.3(1.1 \text { to } \\
1.5)\end{array}$ & $28(16$ to 85$)$ \\
\hline Constipation & 4 & 3986 & 15 & 3.3 & $\begin{array}{l}4.5(3.4 \text { to } \\
6.0)\end{array}$ & $13(10$ to 18$)$ \\
\hline Hot flush & 4 & 3986 & 11 & 2.2 & $\begin{array}{l}4.9(3.4 \text { to } \\
7.1)\end{array}$ & $20(15$ to 29$)$ \\
\hline Dizziness & 4 & 3986 & 10 & 5.8 & $\begin{array}{l}1.8 \text { (1.4 to } \\
2.3)\end{array}$ & 24 (16 to 46$)$ \\
\hline Palpitations & 4 & 3986 & 7.1 & 2.5 & $\begin{array}{l}3.1 \text { ( } 2.2 \text { to } \\
4.3)\end{array}$ & 25 (17 to 42$)$ \\
\hline Insomnia & 4 & 3986 & 11 & 7.7 & $\begin{array}{l}1.3(1.1 \text { to } \\
1.6)\end{array}$ & $\begin{array}{l}44 \text { ( } 22 \text { to } \\
235)\end{array}$ \\
\hline Tachycardia/increased heart rate & 4 & 3986 & 5.9 & 0.9 & $\begin{array}{l}5.2(3.2 \text { to } \\
8.6)\end{array}$ & 41 (27 to 67$)$ \\
\hline Hyperhidrosis & 3 & 3109 & 8.4 & 1.5 & $\begin{array}{l}5.2(3.15 \text { to } \\
8.6)\end{array}$ & $29(19$ to 48$)$ \\
\hline Vomiting & 3 & 2961 & 6.0 & 1.8 & $\begin{array}{l}3.4 \text { ( } 2.0 \text { to } \\
5.7)\end{array}$ & 38 (21 to 94$)$ \\
\hline Hypertension & 2 & 2221 & 5.1 & 1.2 & $\begin{array}{l}4.1(2.2 \text { to } \\
7.7)\end{array}$ & 40 (22 to 86$)$ \\
\hline Diarrhoea & 3 & 3109 & 4.6 & 5.8 & $\begin{array}{l}0.76(0.56 \text { to } \\
1.04)\end{array}$ & not calculated \\
\hline Sinusitis & 2 & 2084 & 6.2 & 5.8 & $\begin{array}{l}1.04(0.72 \text { to } \\
1.5)\end{array}$ & not calculated \\
\hline Fatigue & 2 & 2221 & 6.4 & 4.8 & $\begin{array}{l}1.3(0.90 \text { to } \\
1.8)\end{array}$ & not calculated \\
\hline Upper respiratory tract infection & 2 & 2091 & 5.8 & 4.7 & $\begin{array}{l}1.2(0.82 \text { to } \\
1.8)\end{array}$ & not calculated \\
\hline
\end{tabular}

Withdrawals: All studies provided data on withdrawals over the study period for all causes, due to lack of efficacy and due to adverse events.

All-cause withdrawals: For $100 \mathrm{mg}$ milnacipran versus placebo, 34\% (390/1139) of those with active treatment and 30\% (339/1133) with placebo withdrew for any reason, giving a relative risk of 1.1 (1.02 to 1.3) and a NNH of 23 (12 to 210), and for milnacipran $200 \mathrm{mg}$ versus placebo, 36\% (488/1364) of those with active treatment and 24\% (268/1098) with placebo withdrew for any reason, giving a relative risk of 1.4 (1.2 to 1.6), and a $\mathrm{NNH}$ of 8.8 (6.7 to 13) (Analysis 1.8; Analysis 2.8; $\mathrm{z}=2.6284, \mathrm{P}=0.009$ for difference between doses).

Lack of efficacy withdrawals: For $100 \mathrm{mg}$ milnacipran versus placebo, $6.8 \%(78 / 1139)$ of those with active treatment and 9.1\% (103/1133) with placebo withdrew due to lack of efficacy, giving a relative risk of 0.8 (0.6 to 1.0) and a NNTp of 45 (22 to 5850), and for milnacipran $200 \mathrm{mg}$ versus placebo, 7.2\% (98/1364) of those with active treatment and 10\% (106/1098) with placebo withdrew due to lack of efficacy, giving a relative risk of 0.66 (0.51 to 0.87), and a NNTp of 41 (21 to 400) (Analysis 1.9; Analysis 2.9). 
Adverse event withdrawals: For $100 \mathrm{mg}$ milnacipran versus placebo, 19\% (214/1139) of those with active treatment and $12 \%(132 / 1133)$ with placebo withdrew due to an adverse event, giving a relative risk of 1.6 (1.3 to 2.0) and a NNH of 14 (10 to 24), and for milnacipran $200 \mathrm{mg}$ versus placebo, 24\% (325/1364) of those with active treatment and 9.5\% (104/1098) with placebo withdrew due to adverse events, giving a relative risk of 2.5 (2.03 to 3.1), and a NNH of 7.0 (5.8 to 8.7) (Analysis 1.10; Analysis 2.10; $\mathrm{z}=3.4566, \mathrm{P}=$ 0.0006 for difference between doses).

Death: No deaths were reported in any of the studies.

\section{DISCUSSION}

\section{Summary of main results}

Participants in these studies were all treated for fibromyalgia and consequently this review can address the use of milnacipran only in the treatment of this condition.

The review included five randomised, double-blind studies in which over 4000 participants were titrated to a target dose of milnacipran $100 \mathrm{mg}$, milnacipran $200 \mathrm{mg}$, or placebo, and assessed following a stable dose period of eight to 24 weeks.

A moderate response was experienced by $40 \%$ of participants treated with either dose of milnacipran, using either measurement, while response to placebo was about $10 \%$ lower (30\%) using at least 30\% pain relief and about $15 \%$ lower (25\%) using Patient Global Impression of Change (PGIC) much or very much improved. Numbers needed to treat to benefit (NNTs) were 6 to 10, with no significant difference between doses or outcome measurement. Only one study reported an outcome equivalent to substantial improvement; milnacipran was numerically better than placebo, but there were too few data for analysis.

Two further outcomes were reported by some studies. These were composite outcomes, one requiring response to both $30 \%$ pain relief and PGIC (Composite 1) and the other requiring response to 30\% pain relief, PGIC, and a measure of physical function (Composite 2). These outcomes, while not prespecified in the protocol, were analysed because they more closely reflect what is desirable in clinical practice, and because they were calculated using baseline observation carried forward, without imputation for missing data, which reflects the real world of clinical practice. Response rates for both doses of milnacipran were around $25 \%$ for Composite 1 and $18 \%$ for composite 2, and $8 \%$ or $9 \%$ lower with placebo, giving NNTs of 11 to 14, with no significant difference between doses or outcome. The higher (worse) NNTs for the composite outcomes reflect the fact that these are more difficult to achieve than the individual components alone, as well as a potential for overestimation of treatment effect with imputation of efficacy results from patients who have withdrawn from the study (Moore 2010a).

Adverse events were experienced by the majority $( \pm 80 \%)$ of participants in all treatment groups, but were slightly more common with milnacipran than placebo, giving a number needed to treat to harm $(\mathrm{NNH})$ of 11 to 13 . There were few serious adverse events $(<2 \%)$ and they were no more frequent with milnacipran than placebo. A number of specific 
adverse events were more common with milnacipran, and in particular nausea and constipation, with NNHs of 7 and 13 respectively. The range of adverse events reported was typical of those associated with serotonin-norepinephrine reuptake inhibitor (SNRIs). There was no difference between the doses. It has been suggested that twice daily dosing is better tolerated than once daily, but only one treatment arm in one study used once daily dosing, so we were unable to evaluate this.

Withdrawals for any reason were more common with milnacipran than placebo, and more common with $200 \mathrm{mg}$ than $100 \mathrm{mg}$ (NNH of 8.8 and 23 respectively, compared with placebo). This was largely driven by adverse event withdrawals, where the NNH compared with placebo was 7.0 for $200 \mathrm{mg}$ and 14 for $100 \mathrm{mg}$. Withdrawals due to lack of efficacy were more common with milnacipran than placebo but did not differ between doses (NNTp of 45 and 41 respectively).

\section{Overall completeness and applicability of evidence}

No studies were identified using milnacipran in other neuropathic pain conditions, and there is no evidence that milnacipran is effective in neuropathic pain. That has not prevented some commentators from suggesting its use (Lee 2010).

Included studies were not of sufficient duration to determine long-term use, but two extension studies have demonstrated efficacy and tolerability up to 12 months (Branco 2011; Goldenberg 2010).

\section{Quality of the evidence}

Studies, with the exception of Vitton 2004, had large sample sizes (> 200 in each arm), thereby minimising the effects of random chance and small study bias. While these studies reported our preferred dichotomous outcome measures, the individual outcomes were analysed using last observation carried forward as the imputation method for missing data. Where there is an imbalance of withdrawals due to lack of efficacy or adverse events between active and placebo treatment arms, this may lead to an overestimate of efficacy (Moore 2010a). For this reason, we chose also to review data on two composite outcomes where present, since these were presented using baseline observation carried forward for withdrawals (i.e. no imputation; withdrawal $=$ non responder). Other aspects of methodological quality were good.

\section{Potential biases in the review process}

We used an extensive search strategy and contacted the manufacturer for information about unpublished or ongoing reviews, but we can never be certain that some studies have not been identified. We calculated the number of participants who would need to be in trials with zero effect (relative risk of 1.0) needed for the point estimate of the NNT to increase beyond a clinically useful level. In this case, we chose a clinically useful level as 12 , and calculated that around 600 participants would have to have been involved in unpublished trials with zero treatment effects for the NNT to increase above that level (Moore 2008). This seems unlikely, but is not impossible, and must be considered alongside the results of this review. 
Of greater concern is the use of last observation carried forward (LOCF) as the imputation method for the primary outcomes of this review. Recent investigations of the effects of imputation methods in chronic pain trials have shown that LOCF overestimates efficacy outcomes compared with calculations where patients who withdraw from treatment are regarded as not being able to have meaningful pain relief (Moore 2011). This is particularly the case where there is an imbalance between comparator groups for withdrawals, especially due to adverse events; this may be particularly important for the $200 \mathrm{mg}$ dose, where there was a $12 \%$ absolute increase in all-cause withdrawals for milnacipran over placebo. Where NNTs are relatively large, as here with milnacipran, results using LOCF can overstate the efficacy of the drug.

\section{Agreements and disagreements with other studies or reviews}

A number of reviews of milnacipran in fibromyalgia were published in 2010; all included Clauw 2008, Mease 2009, and Vitton 2004, but predate publication of Arnold 2010 and Branco 2010 (other than as a abstract). Kyle 2010, Recla 2010, and Ormseth 2010 did not carry out any meta-analyses, but reported that milnacipran was effective and reasonably well tolerated. Roskell 2011 carried out meta-analysis and concluded that milnacipran was effective, but did not report NNTs. Hauser 2010 compared pregabalin, duloxetine, and milnacipran (apparently all doses combined), and reported a slightly higher NNT for at least $30 \%$ pain relief (19, versus 10 for $200 \mathrm{mg}$ in this review), a lower NNTp for lack of efficacy (31 versus 41), and a similar NNH for adverse event withdrawals (7.6 versus 7.0). These differences can be explained by the fact that fewer studies were included.

More recently Hauser et al updated their indirect comparisons of duloxetine and milnacipran to incorporate the two most recent studies, and to add a comparison with amitriptyline (Hauser 2011). No data were reported in a way that could be compared with this review.

\section{AUTHORS' CONCLUSIONS}

\section{Implications for practice}

Milnacipran $100 \mathrm{mg}$ or $200 \mathrm{mg}$ daily, as a divided dose, can provide a moderate level of pain relief, equivalent to at least $30 \%$ reduction, to a minority of individuals with fibromyalgia. About 10\% more participants will have this level of benefit with milnacipran than with placebo. Since no single treatment is effective in a majority of individuals with this condition, this relatively small number who benefit may be considered worthwhile. Potential benefit is accompanied by increased numbers experiencing adverse events and stopping their medication.

Since relatively few participants achieve a worthwhile response with milnacipran, it is important to establish stopping rules, so that when an individual does not respond within a specified time, they can be switched to an alternative treatment. This will reduce the number of participants exposed to adverse events in the absence of benefit. 


\section{Implications for research}

High-quality studies are needed to investigate the use of milnacipran in chronic neuropathic pain conditions; one study in idiopathic neuropathy pain is currently recruiting (NCT01288937). Another area in need of research is evaluation of milnacipran as an add-on therapy. One open-label study adding milnacipran to pregabalin in fibromyalgia is completed, but high-quality, double-blind studies are required.

\section{Acknowledgments}

We would like to thank several peer reviewers for constructive criticism, and the excellent editorial support of the Cochrane PaPaS Group.

\section{SOURCES OF SUPPORT}

Internal sources

- Oxford Pain Research Trust, UK.

External sources

- $\quad$ No sources of support supplied

\section{Appendix 1. MEDLINE (via OVID) search strategy}

1. $\exp$ PAIN/

2. exp PERIPHERAL NERVOUS SYSTEM DISEASES/

3. $\exp$ SOMATOSENSORY DISORDERS/

4. FIBROMYALGIA/ or exp MYOFASCIAL PAIN SYNDROMES/ or POLYMYALGIA RHEUMATICA/

5. ((pain* or discomfort*) adj10 (central or complex or rheumat* or muscl* or muscul* or myofasci* or nerv* or neuralg* or neuropath*)).mp.

6. (fibromyalgi* or fibrosti* or FM or FMS).mp.

7. ((neur* or nerv*) adj6 (compress* or damag*)).mp.

8. 1 or 2 or 3 or 4 or 5 or 6 or 7

9. milnacipr*.mp.

10. (F-2207 or Midalcipran or Dalcipran or Ixel or Toledomin or Savella or Milnatsiprana or Iksel).mp.

11. 9 or 10

12. 8 and 11

13. randomized controlled trial.pt.

14. controlled clinical trial.pt.

15. randomized.ab.

16. placebo.ab. 
17. drug therapy.fs.

18. randomly.ab.

19. trial.ab.

20. groups.ab.

21. or $/ 13-20$

22. exp animals/ not humans.sh.

23. 21 not 22

24. 23 and 12

\section{Appendix 2. EMBASE (via OVID) search strategy}

1. exp chronic pain/

2. exp peripheral neuropathy/

3. exp somatosensory disorder/

4. fibromyalgia/ or exp myofascial pain/ or rheumatic polymyalgia/

5. ((pain* or discomfort*) adj10 (central or complex or rheumat* or muscl* or muscul* or myofasci* or nerv* or neuralg* or neuropath*)).mp.

6. (fibromyalgi* or fibrosti* or FM or FMS).mp.

7. ((neur* or nerv*) adj6 (compress* or damag*)).mp.

8. 1 or 2 or 3 or 4 or 5 or 6 or 7

9. milnacipr*.mp.

10. (F-2207 or Midalcipran or Dalcipran or Ixel or Toledomin or Savella or Milnatsiprana or Iksel).mp.

11. 9 or 10

12. 8 and 11

13. random*.ti,ab.

14. factorial*.ti,ab.

15. (crossover* or cross over* or cross-over*).ti,ab.

16. placebo*.ti,ab.

17. (doubl* adj blind*).ti,ab.

18. assign*.ti,ab.

19. allocat*.ti,ab.

20. RANDOMIZED CONTROLLED TRIAL.sh.

21. DOUBLE-BLIND PROCEDURE.sh. 
22. CROSSOVER PROCEDURE.sh.

23. 13 or 14 or 15 or 16 or 17 or 18 or 19 or 20 or 21 or 22

24. 12 and 23

\section{Appendix 3. CENTRAL search strategy}

1. MeSH descriptor Pain explode all trees

2. MeSH descriptor Peripheral Nervous System Diseases explode all trees

3. MeSH descriptor Somatosensory Disorders explode all trees

4. MeSH descriptor Fibromyalgia, this term only

5. MeSH descriptor Myofascial Pain Syndromes explode all trees

6. MeSH descriptor Polymyalgia Rheumatica explode all trees

7. ((pain* or discomfort*) and (central or complex or rheumat* or muscl* or muscul* or myofasci* or nerv* or neuralg* or neuropath*)):ti,ab,kw

8. (fibromyalgi* or fibrosti* or FM or FMS):ti,ab,kw

9. ((neur* or nerv*) and (compress* or damag*)):ti,ab,kw

10. ( 1 or 2 or 3 or 4 or 5 or 6 or 7 or 8 or 9 )

11. milnacipr*.ti,ab,kw 12. (F-2207 or Midalcipran or Dalcipran or Ixel or Toledomin or Savella or Milnatsiprana or Iksel).ti,ab,kw

12. 11 or 12

13. 10 and 13

14. Limit 14 to CENTRAL

\section{Appendix 4. Summary of outcomes: efficacy}

\begin{tabular}{|c|c|c|c|c|c|}
\hline Study & Patient characteristics & $\begin{array}{l}\text { Maximum } \\
\text { daily dose of } \\
\text { carbamazepine } \\
\text { Titration/fixed }\end{array}$ & Numbers in trial & Efficacy Single endpoint & Efficacy Composite endpoint \\
\hline Arnold 2010 & $\begin{array}{l}\text { M } 48, \text { F } 977 \\
\text { Mean age } 49 \text { years } \\
91 \% \text { white } \\
\text { Mean duration of } \\
\text { symptoms } 10.8 \text { years } \\
\text { Baseline PI }>60 / 100 \\
\text { mm }\end{array}$ & $\begin{array}{l}1 \text { to } 4 \text {-week } \\
\text { screening and } \\
\text { washout } \\
4 \text { to 6-week } \\
\text { flexible dose } \\
\text { titration } \\
\text { 12-week stable } \\
\text { dose } 2 \text {-week } \\
\text { randomised } \\
\text { discontinuation } \\
\text { (not considered } \\
\text { here) } \\
\text { Target dose } 100 \\
\text { mg daily }(2 \times \\
50 \text { mg) } \\
\text { Treatment } \\
\text { duration } \\
\text { Max } 18 \text { weeks }\end{array}$ & $\begin{array}{l}\mathrm{N}=1025 \\
\text { Miln }=516 \\
\text { Plac }=509\end{array}$ & $\begin{array}{l}\text { LOCF } \\
\text { 24-h recall PI* } \geq 30 \% \\
\text { improvement from b'line } \\
\text { Miln }=230 / 516 \\
\text { Plac }=156 / 509 \\
24-h \text { recall PI* } \geq 50 \% \\
\text { improvement from b'line } \\
\text { Miln }=143 / 516 \\
\text { Plac }=92 / 509 \\
\text { PGIC much improved } \\
\text { Miln }=216 / 516 \\
\text { Plac }=132 / 509 \\
\text { PCS } \geq 6-\text { pt improved } \\
\text { Miln }=206 / 516 \\
\text { Plac }=157 / 509 \\
* \text { time weighted average } \\
\text { (AUC) of mean weekly }\end{array}$ & $\begin{array}{l}\text { BOCF } \\
\text { At end of stable dose period } \\
1 . \geq 30 \% \text { improvement from } \\
\text { b'line PI + PGIC much or } \\
\text { very much improved } \\
\text { Miln }=150 / 516 \\
\text { Plac }=92 / 509 \\
2 . \geq 30 \% \text { improvement from } \\
\text { b'line PI + PGIC much or } \\
\text { very much improved }+\geq 6- \\
\text { point improvement in physical } \\
\text { function } \\
\text { Miln }=103 / 516 \\
\text { Plac }=56 / 509\end{array}$ \\
\hline
\end{tabular}




\begin{tabular}{|c|c|c|c|c|c|}
\hline Study & Patient characteristics & $\begin{array}{l}\text { Maximum } \\
\text { daily dose of } \\
\text { carbamazepine } \\
\text { Titration/fixed }\end{array}$ & Numbers in trial & Efficacy Single endpoint & Efficacy Composite endpoint \\
\hline & & Stable 12 weeks & & $\begin{array}{l}\text { PED 24-h re call pain } \\
\text { scores }\end{array}$ & \\
\hline Branco 2010 & $\begin{array}{l}\text { M 58, F } 826 \\
\text { Mean age } 49 \text { years } \\
\text { Mean duration } \\
\text { symptoms } 9.5 \text { years }\end{array}$ & $\begin{array}{l}1 \text { to } 4 \text {-week } \\
\text { washout } \\
\text { 2-week training } \\
\text { and } \\
\text { randomisation } \\
\text { 4-week dose } \\
\text { escalation } \\
\text { 12-week stable } \\
\text { dose } \\
\text { 9-day down- } \\
\text { titration } \\
\text { 2-week follow- } \\
\text { up } \\
\text { Target dose 200 } \\
\text { mg daily (2× } \\
100 \text { mg) } \\
\text { Treatment } \\
\text { duration } \\
\text { Max } 16 \text { weeks } \\
\text { Stable } 12 \text { weeks }\end{array}$ & $\begin{array}{l}\mathrm{N}=884 \\
\text { Milnacipran }= \\
435 \\
\text { Placebo }=449\end{array}$ & $\begin{array}{l}\text { LOCF } \\
\text { At end of stable dose } 24- \\
\text { h recall PI** } \geq 30 \% \\
\text { improvement from b'line } \\
\text { Miln: } 38.6 \%=166 / 430 \\
\text { Plac: } 30.0 \%=134 / 446 \\
\text { PGIC much or very much } \\
\text { improved } \\
\text { Miln: } 33.3 \%=143 / 430 \\
\text { Plac: } 20.6 \%=92 / 446 \\
\text { FIQ total score mean } \\
\text { change (SEM) } \\
\text { Miln: }-14.18(1.03) \\
\text { Plac: }-11.18(0.99) \\
\text { PCS mean change } \\
\text { (SEM): } \\
\text { Miln: } 4.55(0.36) \\
\text { Plac: } 3.57(0.35) \\
\text { ** daily PI averaged for } \\
2 \text { weeks immediately } \\
\text { preceding visit day }\end{array}$ & $\begin{array}{l}\text { BOCF } \\
\text { At end of stable dose period } \\
1 . \geq 30 \% \text { improvement from } \\
\text { b'line PI + PGIC much or } \\
\text { very much improved } \\
\text { Miln: } 100 / 430 \\
\text { Plac: } 60 / 446\end{array}$ \\
\hline Clauw 2008 & $\begin{array}{l}\text { M 45, F } 1151 \\
\text { Mean age } 50 \text { years } \\
93 \% \text { white } \\
\text { Mean duration of } \\
\text { symptoms } 10 \text { years } \\
\text { Baseline PI > 60/100 } \\
\text { mm }\end{array}$ & $\begin{array}{l}1 \text { to } 4 \text {-week } \\
\text { washout, } \\
\text { 2-week } \\
\text { training, } \\
\text { randomisation } \\
\text { 3-week dose } \\
\text { escalation } \\
\text { 12-week stable } \\
\text { dose } \\
\text { Target dose } 100 \\
\mathrm{mg}(2 \times 50) \text { or } \\
200 \mathrm{mg}(2 \times \\
100) \text { daily } \\
\text { Treatment } \\
\text { duration } \\
\text { Max } 15 \text { weeks } \\
\text { Stable } 12 \text { weeks }\end{array}$ & $\begin{array}{l}\mathrm{N}=1207(\mathrm{ITT} \\
1196) \\
\text { Milnacipran } 100 \\
\mathrm{mg} / \mathrm{d}=401(399) \\
\text { Milnacipran 200 } \\
\mathrm{mg} / \mathrm{d}=401(396) \\
\text { Placebo = 405 } \\
(401)\end{array}$ & $\begin{array}{l}\text { LOCF } \\
\text { At end of stable dose } 24- \\
\text { h recall PI** } \geq 30 \% \\
\text { improvement from b'line } \\
\text { Miln } 100=149 / 399 \\
\text { Miln } 200=158 / 396 \\
\text { Plac }=115 / 401 \\
\text { PGIC } \geq \text { much improved } \\
\text { Miln } 100=138 / 399 \\
\text { Miln } 200=151 / 396 \\
\text { Plac }=100 / 401 \\
\text { PCS } \geq 6 \text {-point improved } \\
\text { Miln } 100=129 / 399 \\
\text { Miln } 200=109 / 396 \\
\text { Plac }=102 / 401 \\
* * \text { daily PI averaged for } \\
2 \text { weeks immediately } \\
\text { preceding visit day }\end{array}$ & $\begin{array}{l}\text { BOCF } \\
\text { At end of stable dose period } \\
1 . \geq 30 \% \text { improvement from } \\
\text { b'line PI + PGIC much or } \\
\text { very much improved } \\
\text { Miln } 100=92 / 399 \\
\text { Miln } 200=102 / 396 \\
\text { Plac }=67 / 401 \\
2.230 \% \text { improvement from } \\
\text { b'line PI + PGIC much or } \\
\text { very much improved }+\geq 6- \\
\text { point improvement in physical } \\
\text { function } \\
\text { Miln } 100=59 / 399 \\
\text { Miln } 200=56 / 396 \\
\text { Plac }=35 / 401\end{array}$ \\
\hline Mease 2008 & $\begin{array}{l}\text { M 39, F } 849 \\
\text { Mean age } 49 \text { years } \\
93 \% \text { white } \\
\text { Mean duration of } \\
\text { symptoms 5.5 years } \\
\text { Baseline PI > 60/100 } \\
\text { mm }\end{array}$ & $\begin{array}{l}1 \text { to } 4 \text { weeks } \\
\text { screening and } \\
\text { wash out } \\
\text { 2-week baseline } \\
\text { and training, } \\
\text { randomisation } \\
\text { 3-week dose } \\
\text { escalation } \\
24 \text { weeks stable } \\
\text { dose } \\
\text { All medication } \\
\text { given as } \\
\text { divided doses, } 2 \\
\times \text { daily } \\
\text { Treatment } \\
\text { duration } \\
\text { Max 27 weeks } \\
\text { Stable 24 weeks }\end{array}$ & $\begin{array}{l}\mathrm{N}=888 \\
\text { Milnacipran } 100 \\
\mathrm{mg} / \text { day }=224 \\
\text { Milnacipran } 200 \\
\mathrm{mg} / \mathrm{day}=441 \\
\text { Placebo }=223\end{array}$ & $\begin{array}{l}\text { Mean data for pain at } 15 \\
\text { and } 27 \text { weeks - } \\
\text { improvements generally } \\
\text { similar between } 2 \text { doses } \\
\geq 30 \% \text { and } \geq 50 \% \\
\text { improvement in PI and } \\
\text { PGIC response: } \% \text { given } \\
\text { for observed cases } \\
\text { (completers) only }\end{array}$ & $\begin{array}{l}\text { BOCF [modified BOCF] } \\
\text { At week } 15 \text { [27] } \\
\text { 1.; } \geq 30 \% \text { improvement from } \\
\text { b'line PI + PGIC much or } \\
\text { very much improved } \\
\text { Miln } 100=61 / 224 \text { [58/224] } \\
\text { Miln } 200=118 / 441[113 / 441] \\
\text { Plac }=43 / 223[41 / 223] \\
\text { At week } 15[27] \\
\text { 2.; } 230 \% \text { improvement from } \\
\text { b'line PI + PGIC much or } \\
\text { very much improved + } \geq 6- \\
\text { point improvement in physical } \\
\text { function } \\
\text { Miln } 100=44 / 224[41 / 224] \\
\text { Miln } 200=85 / 441[80 / 441] \\
\text { Plac }=27 / 223[29 / 223]\end{array}$ \\
\hline Vitton 2004 & $\begin{array}{l}\text { Across groups: } \\
\text { F } 96 \% \text { to } 98 \% \\
\text { Mean age } 46 \text { to } 48 \\
\text { years } \\
\text { Caucasian } 79 \% \text { to } 89 \% \\
\text { Mean duration of } \\
\text { symptoms } 3.8 \text { to } 4.3 \\
\text { years }\end{array}$ & $\begin{array}{l}1 \text { to } 4 \text { weeks } \\
\text { screening and } \\
\text { washout } \\
2 \text {-week } \\
\text { baseline/ } \\
\text { training, } \\
\text { randomisation } \\
\text { 4-week dose } \\
\text { titration }\end{array}$ & $\begin{array}{l}\mathrm{N}=125 \\
\text { Milnacipran } 2 \times \\
100 \mathrm{mg} / \text { day }=51 \\
\text { Milnacipran } 1 \times \\
200 \mathrm{mg} / \text { day }=46 \\
\text { Placebo }=28\end{array}$ & $\begin{array}{l}\text { LOCF } \\
\text { Gracely PI } \geq 50 \% * * *: \\
\text { Miln } 2 \times 100=18 / 51 \\
\text { Miln } 1 \times 200=10 / 46 \\
\text { Plac }=4 / 28 \\
\text { VAS PI } \leq 30 \% * * *: \\
\text { Miln } 2 \times 100=20 / 51 \\
\text { Miln } 1 \times 200=16 / 46 \\
\text { Plac }=6 / 28\end{array}$ & None \\
\hline
\end{tabular}




\begin{tabular}{|c|c|c|c|c|c|}
\hline Study & Patient characteristics & $\begin{array}{l}\text { Maximum } \\
\text { daily dose of } \\
\text { carbamazepine } \\
\text { Titration/fixed }\end{array}$ & Numbers in trial & Efficacy Single endpoint & Efficacy Composite endpoint \\
\hline & & $\begin{array}{l}\text { 8-week stable } \\
\text { dose } \\
\text { Milnacipran } \\
\text { given as single } \\
\text { or divided dose } \\
\text { Treatment } \\
\text { duration } \\
\text { Max 12 weeks } \\
\text { Stable } 8 \text { weeks }\end{array}$ & & $\begin{array}{l}\text { VAS PI } 250 \% * * *: \\
\text { Miln } 2 \times 100=15 / 51 \\
\text { Miln } 1 \times 200=12 / 46 \\
\text { Plac }=6 / 28 \\
\text { PGIC } \\
\text { "improved" }(1-3) \text { for } \\
\text { completers only } * * * \\
\text { daily PI (Gracely scale) } \\
\text { averaged for } 2 \text { weeks } \\
\text { immediately preceding } \\
\text { visit day and compared } \\
\text { with 2-week baseline } \\
\text { period }\end{array}$ & \\
\hline
\end{tabular}

AUC - area under the curve; b'line - baseline; BOCF - baseline observation carried forward; FIQ - fibromyalgia impact questionnaire; h - hour; ITT - intention-to-treat; LOCF - last observation carried forward; Miln - milnacipran; $\mathrm{N}$ - total number of participants in study; PCS - physical component summary; PED - patient experience diary; PGIC - patient global impression of change; PI - pain intensity; Plac - placebo; SEM - standard error of the mean; VAS - visual analogue scale

\section{Appendix 5. Summary of results: adverse events and withdrawals}

\begin{tabular}{|c|c|c|c|}
\hline Study & Adverse events (general) & Adverse events (specific) & Withdrawals \\
\hline Arnold 2010 & $\begin{array}{l}\text { Pts with } \geq 1 \\
\text { Miln }=434 / 516 \\
\text { Plac }=382 / 509 \\
\text { Most mild to moderate } \\
\text { SAE: } \\
\text { Miln }=8 / 516 \\
\text { Plac }=6 / 509 \\
\text { No deaths }\end{array}$ & $\begin{array}{l}\text { In } \geq 5 \% \\
\text { Nausea: Miln 189/516, Plac 106/509 } \\
\text { Headache: Miln 92/516, Plac 80/509 } \\
\text { Constipation: Miln 76/516, Plac 20/509 } \\
\text { Hot flush: Miln 56/516, Plac 18/509 } \\
\text { Dizziness: Miln 54/516, Plac 26/509 } \\
\text { Insomnia: Miln 51/516, Plac 41/509 } \\
\text { Hyperhidrosis: Miln 40/516, Plac 7/509 } \\
\text { Palpitations: Miln 38/516, Plac 15/509 } \\
\text { Fatigue: Miln 31/516, Plac 22/509 }\end{array}$ & $\begin{array}{l}\text { Miln } \\
\text { All-cause }=159 \\
\text { AE }=92 \\
\text { LoE }=24 \\
\text { Pt consent }=27 \\
\text { Plac } \\
\text { All-cause = } 150 \\
\text { AE }=71 \\
\text { LoE }=33 \\
\text { Pt consent }=21\end{array}$ \\
\hline Branco 2010 & $\begin{array}{l}\text { Pts with } \geq 1 \\
\text { Miln: } 363 / 431 \\
\text { Plac: } 331 / 446 \\
\text { Most mild to moderate, and in } \\
\text { titration period } \\
\text { SAE } \\
\text { Miln: } 11 / 431 \text { ( } 14 \text { events) } \\
\text { Plac: } 11 / 446 \text { ( } 16 \text { events) } \\
\text { No deaths }\end{array}$ & $\begin{array}{l}\text { In } \geq 5 \% \\
\text { Nausea: Miln 112/431, Plac 50/446 } \\
\text { Hyperhidrosis: Miln 102/431, Plac 13/446 } \\
\text { Headache: Miln 73/431, Plac 55/446 } \\
\text { Constipation: Miln 54/431, Plac 10/446 } \\
\text { Dizziness: Miln 44/431, Plac 34/446 } \\
\text { Palpitations: Miln 34/431, Plac 13/446 } \\
\text { Insomnia: Miln 33/431, Plac 24/446 } \\
\text { Nasopharyngitis: Miln 33/431, Plac } \\
\text { 33/446 } \\
\text { Hot flush: Miln 30/431, Plac 5/446 } \\
\text { Tachycardia: Miln 29/431, Plac 3/446 } \\
\text { Vomiting: 22/431, Plac 15/446 }\end{array}$ & $\begin{array}{l}\text { Miln } \\
\text { All-cause = } 119 \\
\mathrm{AE}=95 \\
\mathrm{LoE}=24 \\
\mathrm{Pt} \text { consent = } 7 \\
\mathrm{Plac} \\
\mathrm{All} \text {-cause = } 72 \\
\mathrm{AE}=42 \\
\mathrm{LoE}=31 \\
\mathrm{Pt} \text { consent = } 7 \\
5 \text { pts with Miln and } 3 \\
\text { with Plac did not have } \\
\text { evaluable data: } \\
\text { problem with one } \\
\text { study centre (4), did } \\
\text { not receive medication } \\
\text { (3), missing baseline } \\
\text { data (1) }\end{array}$ \\
\hline Clauw 2008 & $\begin{array}{l}\text { Pts with } \geq 1 \\
\text { Miln } 100=358 / 399 \\
\text { Miln } 200=346 / 396 \\
\text { Plac }=317 / 401 \\
\text { Most mild to moderate } \\
\text { SAE } \\
\text { Miln } 100=5 / 399 \\
\text { Miln } 200=4 / 396 \\
\text { Plac }=6 / 401 \\
\text { No deaths }\end{array}$ & $\begin{array}{l}\text { In } \geq 5 \% \text { active group: } \\
\text { Nausea: Miln } 100137 / 399 \text {, Miln } 200 \\
\text { 149/396, Plac 77/401 } \\
\text { Headache: Miln } 100 \text { 72/399, Miln } 200 \\
\text { 70/396, Plac 58/401 } \\
\text { Constipation: Miln } 100 \text { 57/399, Miln } 200 \\
\text { 71/396, Plac } 16 / 401 \\
\text { Insomnia: Miln } 100 \text { 42/399, Miln 62/396, } \\
\text { Plac 42/401 } \\
\text { Hot flush: Miln } 100 \text { 46/399, Miln } 200 \\
\text { 58/396, Plac 5/401 }\end{array}$ & $\begin{array}{l}\text { Miln } 100 \\
\text { All-cause }=135 \\
\mathrm{AE}=78 \\
\text { LoE }=28 \\
\text { Pt consent }=14 \\
\text { Miln } 200 \\
\text { All-cause }=139 \\
\mathrm{AE}=94 \\
\text { LoE }=19 \\
\text { Pt consent }=15 \\
\text { Placebo } \\
\text { All-cause }=111\end{array}$ \\
\hline
\end{tabular}




\begin{tabular}{|c|c|c|c|}
\hline Study & Adverse events (general) & Adverse events (specific) & Withdrawals \\
\hline & & $\begin{array}{l}\text { Dizziness: Miln } 100 \text { 38/399, Miln } 200 \\
\text { 36/396, Plac } 17 / 401 \\
\text { Palpitations: Miln } 100 \text { 26/399, Miln } 200 \\
\text { 30/396, Plac 10/401 } \\
\text { Fatigue: Miln } 100 \text { 25/399, Miln } 200 \\
\text { 28/396, Plac 22/401 } \\
\text { Sinusitis: Miln } 111 \text { 22/399, Miln } 200 \\
\text { 26/396, Plac } 18 / 401 \\
\text { Hyperhidrosis: Miln } 100 \text { 25/399, Miln } 200 \\
\text { 23/396, Plac 5/401 } \\
\text { Hypertension: Miln } 100 \text { 25/399, Miln } 200 \\
\text { 15/396, Plac 6/401 } \\
\text { Vomiting: Miln } 100 \text { 24/399, Miln } 200 \\
\text { 20/396, Plac 9/401 } \\
\text { Diarrhoea: Miln } 100 \text { 22/399, Miln } 200 \\
\text { 13/396, Plac 24/401 } \\
\text { Inc heart rate: Miln } 100 \text { 20/399, Miln } 200 \\
\text { 21/396, Plac } 1 / 401 \\
\text { Migraine: Miln } 100 \text { 20/399, Miln } 200 \\
\text { 20/396, Plac 9/401 } \\
\text { Depression: Miln } 100 \text { 14/399, Miln } 200 \\
\text { 12/396, Plac 24/401 }\end{array}$ & $\begin{array}{l}\mathrm{AE}=38 \\
\mathrm{LoE}=36 \\
\text { Pt consent }=20 \\
2 \text { pts with Miln 100, } 5 \\
\text { with Miln 200, and } 4 \\
\text { with Plac excluded } \\
\text { from all analyses: } \\
\text { problem with one } \\
\text { study centre (9), did } \\
\text { not receive medication } \\
(1), \text { enrolled at } 2 \\
\text { centres (1) }\end{array}$ \\
\hline Mease 2008 & $\begin{array}{l}\text { Pts with } \geq 1: \\
\text { Miln } 100=188 / 224 \\
\text { Miln } 200=400 / 441 \\
\text { Plac }=190 / 223 \\
\text { Most mild or moderate } \\
\text { SAE: } \\
\text { Miln } 100=3 / 224 \\
\text { Miln } 200=11 / 441 \\
\text { Plac }=6 / 223\end{array}$ & $\begin{array}{l}\text { In } 25 \%: \\
\text { Nausea: Miln } 100=73 / 224, \text { Miln } 200= \\
177 / 441, \text { Plac }=47 / 223 \\
\text { Headache: Miln } 100=35 / 224, \text { Miln } 200= \\
78 / 441, \text { Plac }=26 / 223 \\
\text { Constipation: Miln } 100=41 / 224, \text { Miln } \\
200=63 / 441, \text { Plac }=6 / 223 \\
\text { Hyperhidrosis: Miln } 100=22 / 224, \text { Miln } \\
200=55 / 441, \text { Plac }=5 / 223 \\
\text { Dizziness: Miln } 100=26 / 224, \text { Miln } 200= \\
\text { 50/441, Plac }=15 / 223 \\
\text { Hot flush: Miln } 100=22 / 224, \text { Miln } 200= \\
46 / 441, \text { Plac }=6 / 223 \\
\text { Insomnia: Miln } 100=24 / 224, \text { Miln } 200= \\
\text { 41/441, Plac }=15 / 223 \\
\text { Vomiting: Miln } 100=11 / 224, \text { Miln } 200= \\
\text { 36/441, Plac }=4 / 223 \\
\text { Sinusitis: Miln } 100=11 / 224, \text { Miln } 200= \\
\text { 32/441, Plac }=18 / 223 \\
\text { Inc heart rate: Miln } 100=12 / 224, \text { Miln } \\
\text { 200 = 32/441, Plac 5/223 } \\
\text { Dry mouth: Miln } 100=13 / 224, \text { Miln } 200 \\
=31 / 441, \text { Plac }=6 / 223 \\
\text { URTI: Miln } 100=20 / 224, \text { Miln } 200= \\
\text { 30/441, Plac }=16 / 223 \\
\text { Palpitations: Miln } 100=18 / 224, \text { Miln } 200 \\
\text { = 25/441, Plac }=2 / 223 \\
\text { Diarrhoea: Miln } 100=10 / 224, \text { Miln } 200= \\
\text { 23/441, Plac }=16 / 223\end{array}$ & $\begin{array}{l}\text { Miln } 100 \\
\text { All-cause }=96 / 224 \\
\mathrm{AE}=44 / 224 \\
\mathrm{LoE}=26 / 224 \\
\text { Miln } 200 \\
\text { All-cause }=202 / 441 \\
\mathrm{AE}=119 / 441 \\
\mathrm{LoE}=49 / 441 \\
\mathrm{Plac} \\
\mathrm{All}-\mathrm{cause}=78 / 223 \\
\mathrm{AE}=23 / 223 \\
\mathrm{LoE}=34 / 223\end{array}$ \\
\hline Vitton 2004 & $\begin{array}{l}\text { No data for pts with } \geq 1 \mathrm{AE} \\
\text { No SAE } \\
\text { Most AE of mild or moderate } \\
\text { intensity }\end{array}$ & No data & $\begin{array}{l}\text { Miln } 2 \times 100 \\
\text { All-cause }=14 / 51 \\
\mathrm{AE}=7 / 51 \\
\mathrm{LoE}=3 / 51 \\
\text { Miln } 1 \times 200 \\
\text { All-cause }=14 / 46 \\
\mathrm{AE}=10 / 46 \\
\mathrm{LoE}=3 / 46 \\
\text { Plac } \\
\mathrm{All}-\text { cause }=7 / 28 \\
\mathrm{AE}=1 / 28 \\
\mathrm{LoE}=5 / 28\end{array}$ \\
\hline
\end{tabular}

AE - adverse event; LoE - lack of efficacy; Miln - milnacipran; Plac - placebo; pt - participant; SAE - serious adverse event 


\section{CHARACTERISTICS OF STUDIES}

\section{Characteristics of included studies [ordered by study ID]}

Arnold 2010

\begin{tabular}{|c|c|c|}
\hline Methods & \multicolumn{2}{|c|}{$\begin{array}{l}\text { Prospective, multicentre, randomised, double-blinded, placebo-controlled trial with parallel groups. } \\
\text { Participants recruited from outpatient clinical/research centres in US and Canada } \\
1 \text { to } 4 \text {-week screening and washout (all FM therapy stopped), } 4 \text { to } 6 \text {-week flexible dose titration, 12- } \\
\text { week stable dose of } 100 \mathrm{mg} / \text { day milnacipran ( } 50 \mathrm{mg} \text { twice daily). } \\
\text { Participants unable to tolerate } 100 \mathrm{mg} \text { daily were discontinued from study } \\
\text { Data collected using electronic patient experience diary (PED); pain improvement based on time } \\
\text { weighted average of mean weekly } 24 \text { h recall pain scores }\end{array}$} \\
\hline Participants & \multicolumn{2}{|c|}{$\begin{array}{l}\text { Inclusion: age } 18 \text { to } 70 \text { years, ACR criteria for FM; physical function (FIQ) } \geq 4 \text {, and BDI }>25 \text { at } \\
\text { screening, mean PI } \geq 40 \text { and } \leq 90 / 100 \text { mm over } 14 \text {-day baseline period } \\
\text { Excluded patients with various medical and psychiatric conditions/risk factors, and previous } \\
\text { exposure to milnacipran; female participants not using adequate contraception } \mathrm{N}=1025 \text { : mean age } \\
\sim 49 \text { years, M:F } 48: 977,91 \% \text { white, mean duration of symptoms } \sim 10.8 \text { years, baseline pain }>60 / 100 \\
\text { mm }\end{array}$} \\
\hline Interventions & \multicolumn{2}{|c|}{$\begin{array}{l}\text { Milnacipran } 100 \mathrm{mg} / \text { day, } \mathrm{n}=516 \\
\text { Placebo, } \mathrm{n}=509 \\
\text { Permitted analgesics: paracetamol, aspirin, NSAIDs } \\
\text { Short-term rescue medication up to week 4: tramadol, hydrocodone }\end{array}$} \\
\hline Outcomes & \multicolumn{2}{|c|}{$\begin{array}{l}\text { Pain intensity using } 100 \mathrm{~mm} \text { VAS: } 30 \% \text { and } 50 \% \text { improvement from baseline } \\
\text { PGIC using 7-point scale: much or very much improved } \\
\text { Composite pain scores: } \\
\text { 2-measure BOCF composite responder criteria: } 24 \mathrm{~h} \text { and weekly recall pain scores using } 100 \mathrm{~mm} \\
\text { VAS } \geq 30 \% \text { and PGIC score 'much' or 'very much' improved on 7-point scale } \\
3 \text {-measure BOCF composite responder criteria: } 24 \mathrm{~h} \text { and weekly recall pain scores using } 100 \mathrm{~mm} \\
\text { VAS } \geq 30 \% \text {, PGIC score 'much' or 'very much' improved on 7-point scale, and SF-36 PCS } \geq 6 \text { - } \\
\text { point improvement } \\
\text { Adverse events } \\
\text { Withdrawals }\end{array}$} \\
\hline Notes & \multicolumn{2}{|c|}{ Oxford Quality Score: $\mathrm{R}=1, \mathrm{DB}=2, \mathrm{~W}=1$. Total $=4$} \\
\hline \multicolumn{3}{|l|}{ Risk of bias } \\
\hline Bias & Authors' judgement & Support for judgement \\
\hline $\begin{array}{l}\text { Random } \\
\text { sequence } \\
\text { generation } \\
\text { (selection bias) }\end{array}$ & Unclear risk & $\begin{array}{l}\text { "Randomization assignments generated in blocks of } \\
\text { four" }\end{array}$ \\
\hline $\begin{array}{l}\text { Allocation } \\
\text { concealment } \\
\text { (selection bias) }\end{array}$ & Low risk & $\begin{array}{l}\text { "Assignments to treatment groups was conducted } \\
\text { centrally (i.e. at the study level) using an interactive } \\
\text { voice response system" }\end{array}$ \\
\hline $\begin{array}{l}\text { Blinding of } \\
\text { participants and } \\
\text { personnel } \\
\text { (performance } \\
\text { bias) } \\
\text { All outcomes }\end{array}$ & Low risk & $\begin{array}{l}\text { "identical-appearing capsules were used by all } \\
\text { patients during all phases of the study" }\end{array}$ \\
\hline $\begin{array}{l}\text { Blinding of } \\
\text { outcome } \\
\text { assessment } \\
\text { (detection bias) } \\
\text { All outcomes }\end{array}$ & Low risk & $\begin{array}{l}\text { "Clinical staff, investigators, patients, and the study } \\
\text { sponsor were blinded to treatment allocation" }\end{array}$ \\
\hline $\begin{array}{l}\text { Incomplete } \\
\text { outcome data } \\
\text { (attrition bias) } \\
\text { All outcomes }\end{array}$ & High risk & $\begin{array}{l}\text { Last observation carried forward in analysis of } \\
\text { individual outcomes, but baseline observation } \\
\text { carried forward in analysis of composite outcomes }\end{array}$ \\
\hline $\begin{array}{l}\text { Selective } \\
\text { reporting } \\
\text { (reporting bias) }\end{array}$ & Low risk & $\begin{array}{l}\text { All relevant outcomes in methods were reported in } \\
\text { some way, although not necessarily as our preferred } \\
\text { outcome }\end{array}$ \\
\hline
\end{tabular}


Branco 2010

\begin{tabular}{|c|c|c|}
\hline Methods & \multicolumn{2}{|c|}{$\begin{array}{l}\text { Prospective, multicentre, randomised, double-blinded, placebo-controlled trial with parallel } \\
\text { groups. Participants recruited from outpatient centres in Europe } \\
1 \text { to 4-week screening and washout (all FM therapy stopped), 4-week dose escalation, 12-week } \\
\text { stable dose with target } 200 \mathrm{mg} / \text { day milnacipran (100 mg twice daily), 9-day down-titration, 2- } \\
\text { week follow-up } \\
\text { Data collected using electronic patient experience diary (PED): daily pain intensity averaged for } 2 \\
\text { weeks immediately preceding visit day } \\
\text { Adverse event data collected by spontaneous reporting, non-leading questions and clinical } \\
\text { evaluation }\end{array}$} \\
\hline Participants & \multicolumn{2}{|c|}{$\begin{array}{l}\text { Inclusion: age } 18 \text { to } 70 \text { years, met ACR criteria for FM; physical function (FIQ) } \geq 3 \text {, BDI }>25 \text { at } \\
\text { screening; mean PI } \geq 40 \text { and } \geq 90 \text { over } 14 \text {-day baseline period } \\
\text { Exclusion: patients with various medical and psychiatric conditions/risk factors, considered } \\
\text { unlikely to comply with treatment; female participants not using adequate contraception or } \\
\text { pregnant } \\
\mathrm{N}=884 \text { : mean age } ~ 49 \text { years, M:F } 58: 826 \text {, mean duration of symptoms } \sim 9.5 \text { years }\end{array}$} \\
\hline Interventions & \multicolumn{2}{|c|}{$\begin{array}{l}\text { Milnacipran } 200 \mathrm{mg} / \mathrm{day}, \mathrm{n}=435 \\
\text { Placebo, } \mathrm{n}=449\end{array}$} \\
\hline Outcomes & \multicolumn{2}{|c|}{$\begin{array}{l}\text { Pain intensity using } 100 \mathrm{~mm} \text { VAS: } 30 \% \text { improvement from baseline } \\
\text { PGIC using 7-point scale: much or very much improved } \\
\text { Composite pain score: } \\
\text { 2-measure BOCF composite responder criteria: } 24 \mathrm{~h} \text { morning recall pain scores } 230 \% \text { using } 100 \\
\text { mm VAS, PGIC score of 'very much' or 'much' improved } \\
\text { Adverse events } \\
\text { Withdrawals }\end{array}$} \\
\hline Notes & \multicolumn{2}{|c|}{ Oxford Quality Score: $\mathrm{R}=1, \mathrm{DB}=2, \mathrm{~W}=1$. Total $=4$} \\
\hline \multicolumn{3}{|l|}{ Risk of bias } \\
\hline Bias & Authors' judgement & Support for judgement \\
\hline $\begin{array}{l}\text { Random sequence } \\
\text { generation } \\
\text { (selection bias) }\end{array}$ & Unclear risk & Not described \\
\hline $\begin{array}{l}\text { Allocation } \\
\text { concealment } \\
\text { (selection bias) }\end{array}$ & Unclear risk & Not described \\
\hline $\begin{array}{l}\text { Blinding of } \\
\text { participants and } \\
\text { personnel } \\
\text { (performance } \\
\text { bias) } \\
\text { All outcomes }\end{array}$ & Low risk & $\begin{array}{l}\text { "In patients receiving placebo, twice-daily sham dosing } \\
\text { was used to maintain blinding" }\end{array}$ \\
\hline $\begin{array}{l}\text { Blinding of } \\
\text { outcome } \\
\text { assessment } \\
\text { (detection bias) } \\
\text { All outcomes }\end{array}$ & Unclear risk & Not described \\
\hline $\begin{array}{l}\text { Incomplete } \\
\text { outcome data } \\
\text { (attrition bias) } \\
\text { All outcomes }\end{array}$ & High risk & $\begin{array}{l}\text { Last observation carried forward in analysis of } \\
\text { individual outcomes, but baseline observation carried } \\
\text { forward in analysis of composite outcomes }\end{array}$ \\
\hline $\begin{array}{l}\text { Selective } \\
\text { reporting } \\
\text { (reporting bias) }\end{array}$ & Low risk & $\begin{array}{l}\text { All relevant outcomes in methods were reported in } \\
\text { some way, although not necessarily as our preferred } \\
\text { outcome }\end{array}$ \\
\hline Size & Low risk & Both groups $>200$ participants \\
\hline
\end{tabular}

Clauw 2008

Cochrane Database Syst Rev. Author manuscript; available in PMC 2014 September 16. 


\begin{tabular}{|c|c|c|}
\hline Methods & \multicolumn{2}{|c|}{$\begin{array}{l}\text { Prospective, multicentre, randomised, double-blinded, placebo-controlled trial with parallel groups. } \\
\text { Participants recruited from outpatient centres in United States } \\
1 \text { to } 4 \text {-week washout (all FM therapy stopped), 3-week dose escalation, 12-week stable dose with } \\
100 \mathrm{mg} / \mathrm{day} \text { ( } 50 \mathrm{mg} \text { twice daily) or } 200 \mathrm{mg} / \text { day ( } 100 \mathrm{mg} \text { twice daily) milnacipran } \\
\text { Data collected using electronic patient experience diary (PED): daily pain intensity averaged for } 2 \\
\text { weeks immediately preceding visit day } \\
\text { Adverse event data collected by spontaneous reporting and clinical evaluation }\end{array}$} \\
\hline Participants & \multicolumn{2}{|c|}{$\begin{array}{l}\text { Inclusion: age } 18 \text { to } 70 \text { years, met ACR criteria for FM, physical function (FIQ) } \geq 4 \text { and BDI }>25 \\
\text { at screening, baseline PI } \geq 40 / 100 \\
\text { Excluded: various medical and psychiatric conditions/risk factors, interfering medication over the } \\
\text { last } 30 \text { days, female participants not using adequate contraception or pregnant } \mathrm{N}=1151: \text { mean age } \\
\sim 50 \text { years, M:F } 45: 1151, \sim 93 \% \text { white, mean duration of symptoms } \sim 10 \text { years, baseline pain }> \\
60 / 100 \mathrm{~mm}\end{array}$} \\
\hline Interventions & \multicolumn{2}{|c|}{$\begin{array}{l}\text { Milnacipran } 100 \mathrm{mg} / \text { day, } \mathrm{n}=401 \text { ( } 396 \text { for analysis) } \\
\text { Milnacipran } 200 \mathrm{mg} / \text { day, } \mathrm{n}=410 \text { ( } 399 \text { for analyses) } \\
\text { Placebo, } \mathrm{n}=405 \text { ( } 401 \text { for analysis) }\end{array}$} \\
\hline Outcomes & \multicolumn{2}{|c|}{$\begin{array}{l}\text { Pain intensity using } 100 \mathrm{~mm} \text { VAS: } 30 \% \text { improvement from baseline } \\
\text { PGIC using 7-point scale: much or very much improved } \\
\text { Composite pain scores: } \\
\text { 2-measure BOCF composite responder criteria: } 24 \mathrm{~h} \text { and weekly recall pain scores using } 100 \mathrm{~mm} \\
\text { VAS } 230 \% \text { and PGIC score 'much' or 'very much' improved on 7-point scale } \\
\text { 3-measure BOCF composite responder criteria: } 24 \mathrm{~h} \text { and weekly recall pain scores using } 100 \mathrm{~mm} \\
\text { VAS } \geq 30 \% \text {, PGIC score 'much' or 'very much' improved on 7-point scale, and SF-36 PCS } \geq 6 \text { - } \\
\text { point improvement } \\
\text { Adverse events } \\
\text { Withdrawals }\end{array}$} \\
\hline Notes & \multicolumn{2}{|c|}{ Oxford Quality Score: $\mathrm{R}=2, \mathrm{DB}=2, \mathrm{~W}=1$, Total $=5 / 5$} \\
\hline \multicolumn{3}{|l|}{ Risk of bias } \\
\hline Bias & Authors' judgement & Support for judgement \\
\hline $\begin{array}{l}\text { Random } \\
\text { sequence } \\
\text { generation } \\
\text { (selection bias) }\end{array}$ & Low risk & $\begin{array}{l}\text { "Randomization lists for each site were generated by } \\
\text { a computer program" }\end{array}$ \\
\hline $\begin{array}{l}\text { Allocation } \\
\text { concealment } \\
\text { (selection bias) }\end{array}$ & Low risk & $\begin{array}{l}\text { "randomization assignments were made via an } \\
\text { interactive voice response system" }\end{array}$ \\
\hline $\begin{array}{l}\text { Blinding of } \\
\text { participants and } \\
\text { personnel } \\
\text { (performance } \\
\text { bias) } \\
\text { All outcomes }\end{array}$ & Low risk & $\begin{array}{l}\text { "Milnacipran and placebo capsules were visually } \\
\text { identical." }\end{array}$ \\
\hline $\begin{array}{l}\text { Blinding of } \\
\text { outcome } \\
\text { assessment } \\
\text { (detection bias) } \\
\text { All outcomes }\end{array}$ & Low risk & $\begin{array}{l}\text { "Clinical staff, investigators, patients, and the study } \\
\text { sponsor were blinded to treatment allocation." }\end{array}$ \\
\hline $\begin{array}{l}\text { Incomplete } \\
\text { outcome data } \\
\text { (attrition bias) } \\
\text { All outcomes }\end{array}$ & High risk & $\begin{array}{l}\text { Last observation carried forward in analysis of } \\
\text { individual outcomes, but baseline observation } \\
\text { carried forward in analysis of composite outcomes }\end{array}$ \\
\hline $\begin{array}{l}\text { Selective } \\
\text { reporting } \\
\text { (reporting bias) }\end{array}$ & Low risk & $\begin{array}{l}\text { All relevant outcomes in methods were reported in } \\
\text { some way, although not necessarily as our preferred } \\
\text { outcome }\end{array}$ \\
\hline Size & Low risk & All groups $>200$ participants \\
\hline
\end{tabular}

Mease 2009 


\begin{tabular}{|c|c|c|}
\hline Methods & \multicolumn{2}{|c|}{$\begin{array}{l}\text { Prospective, multicentre, randomised, double-blinded, placebo-controlled trial with parallel groups. } \\
\text { Participants recruited from } 59 \text { outpatient clinical/research centres in the United States } \\
\text { Electronic patient experience diary (PED) used to collect data; } 1 \text { to } 4 \text {-week screening and washout } \\
\text { (all FM therapy stopped), 3-week baseline measurement and PED training, 24-week stable dose } \\
\text { with placebo or } 100 \mathrm{mg} / \mathrm{day} \text { milnacipran ( } 50 \mathrm{mg} \text { twice daily) or } 200 \mathrm{mg} / \mathrm{day} \text { (100 mg twice daily) } \\
\text { milnacipran (ratio } 1: 1: 2 \text { respectively) } \\
\text { Adverse events collected from spontaneous reports, clinical observation and clinical evaluation }\end{array}$} \\
\hline Participants & \multicolumn{2}{|c|}{$\begin{array}{l}\text { Inclusion: age } 18 \text { to } 70 \text { years, met ACR criteria for FM, physical function }(\mathrm{FIQ}) \geq 4, \mathrm{BDI}>25 \text {, and } \\
\mathrm{PI}>50 / 100 \mathrm{~mm} \\
\text { Exclusion: patients with various medical and psychiatric conditions/risk factors; female participants } \\
\text { not using adequate contraception } \\
\mathrm{N}=888: \text { mean age } \sim 49 \text { years, M:F } 39: 849, \sim 93 \% \text { white, mean duration of symptoms } \sim 5.5 \text { years, } \\
\text { baseline PI }>60 / 100 \text { at screening } \\
\text { Analgesics prohibited, except for acetaminophen, aspirin, stable doses of NSAIDs, and } \\
\text { hydrocortisone }\end{array}$} \\
\hline Interventions & \multicolumn{2}{|c|}{$\begin{array}{l}\text { Milnacipran } 100 \mathrm{mg} / \text { day, } \mathrm{n}=224 \\
\text { Milnacipran } 200 \mathrm{mg} / \mathrm{day}, \mathrm{n}=441 \\
\text { Placebo, } \mathrm{n}=223\end{array}$} \\
\hline Outcomes & \multicolumn{2}{|c|}{$\begin{array}{l}\text { Composite pain scores: } \\
\text { 2-measure BOCF composite responder criteria: } 24 \mathrm{~h} \text { and 2-week average recall pain scores using } \\
100 \mathrm{~mm} \text { VAS } \geq 30 \% \text { and PGIC score 'much' or 'very much' improved on 7-point scale } \\
3 \text {-measure BOCF composite responder criteria: } 24 \mathrm{~h} \text { and weekly recall pain scores using } 100 \mathrm{~mm} \\
\text { VAS } \geq 30 \% \text {, PGIC score 'much' or 'very much' improved on 7-point scale, and SF-36 PCS } \geq 6 \text { - } \\
\text { point improvement } \\
\text { Adverse events } \\
\text { Withdrawals }\end{array}$} \\
\hline Notes & \multicolumn{2}{|c|}{ Oxford Quality Score: $\mathrm{R}=1, \mathrm{DB}=1, \mathrm{~W}=1$. Total $=3 / 5$} \\
\hline \multicolumn{3}{|l|}{ Risk of bias } \\
\hline Bias & Authors' judgement & Support for judgement \\
\hline $\begin{array}{l}\text { Random } \\
\text { sequence } \\
\text { generation } \\
\text { (selection bias) }\end{array}$ & Unclear risk & No described \\
\hline $\begin{array}{l}\text { Allocation } \\
\text { concealment } \\
\text { (selection bias) }\end{array}$ & Unclear risk & Not described \\
\hline $\begin{array}{l}\text { Blinding of } \\
\text { participants and } \\
\text { personnel } \\
\text { (performance } \\
\text { bias) } \\
\text { All outcomes }\end{array}$ & Unclear risk & Not described \\
\hline $\begin{array}{l}\text { Blinding of } \\
\text { outcome } \\
\text { assessment } \\
\text { (detection bias) } \\
\text { All outcomes }\end{array}$ & Unclear risk & Not described \\
\hline $\begin{array}{l}\text { Incomplete } \\
\text { outcome data } \\
\text { (attrition bias) } \\
\text { All outcomes }\end{array}$ & High risk & $\begin{array}{l}\text { Last observation carried forward in individual } \\
\text { outcome analysis }\end{array}$ \\
\hline $\begin{array}{l}\text { Selective } \\
\text { reporting } \\
\text { (reporting bias) }\end{array}$ & Low risk & $\begin{array}{l}\text { All relevant outcomes in methods were reported in } \\
\text { some way, although not necessarily as our } \\
\text { preferred outcome }\end{array}$ \\
\hline Size & Low risk & All groups $>200$ participants \\
\hline
\end{tabular}

Vitton 2004 


\begin{tabular}{|c|c|c|}
\hline Methods & \multicolumn{2}{|c|}{$\begin{array}{l}\text { Prospective, multicentre, randomised, double-blinded, placebo-controlled trial with parallel groups } \\
\text { Participants recruited from outpatient centres in US with experience in treating fibromyalgia } \\
\text { Electronic patient experience diary (PED) used to collect data; } 1 \text { to 4-week screening and washout } \\
\text { (all FM therapy stopped), } 2 \text { week baseline measurement and PED training, 4-week dose titration, } \\
\text { 8-week stable dose with } 200 \mathrm{mg} / \text { day milnacipran (once daily), } 200 \mathrm{mg} / \text { day milnacipran (100 mg } \\
\text { twice daily), or placebo (ratio 3:3:2 respectively) } \\
\text { Adverse events collected from spontaneous reports, clinical observation and clinical evaluation }\end{array}$} \\
\hline Participants & \multicolumn{2}{|c|}{$\begin{array}{l}\text { Inclusion: age } 18 \text { to } 70 \text { years, met ACR criteria for FM; baseline PI } \geq 10 / 20 \text { (Gracely log-scale) } \\
\text { Exclusion: patients with various medical and psychiatric conditions/risk factors, female } \\
\text { participants not using adequate contraception } \\
\mathrm{N}=125 \text { participants; mean age } 46 \text { to } 48 \text { years, } 96 \% \text { to } 98 \% \text { female, } 79 \% \text { to } 89 \% \\
\text { Caucasian, mean duration of symptoms } 3.8 \text { to } 4.3 \text { years } \\
\text { Analgesics prohibited, except for stable doses of acetaminophen, aspirin, and NSAIDs }\end{array}$} \\
\hline Interventions & \multicolumn{2}{|c|}{$\begin{array}{l}\text { Milnacipran } 200 \mathrm{mg} / \text { day (once daily), } \mathrm{n}=46 \\
\text { Milnacipran } 200 \mathrm{mg} / \text { day (twice daily), } \mathrm{n}=51 \\
\text { Placebo comparator, } \mathrm{n}=28\end{array}$} \\
\hline Outcomes & \multicolumn{2}{|c|}{$\begin{array}{l}\text { Pain (Short-form McGill Pain Questionnaire, visual analogue scale, Gracely and Kwilosz anchored } \\
\text { logarithmic scale) PGIC at end of study (completers analysis only) } \\
\text { Adverse events } \\
\text { Withdrawals }\end{array}$} \\
\hline Notes & \multicolumn{2}{|c|}{$\begin{array}{l}\text { Oxford Quality Score: } \mathrm{R}=2 \text { (from Gendreau 2005), } \mathrm{DB}=2 \text { (from Gendreau 2005), } \mathrm{W}=1 . \text { Total }= \\
5 / 5\end{array}$} \\
\hline \multicolumn{3}{|l|}{ Risk of bias } \\
\hline Bias & Authors' judgement & Support for judgement \\
\hline $\begin{array}{l}\text { Random } \\
\text { sequence } \\
\text { generation } \\
\text { (selection bias) }\end{array}$ & Low risk & $\begin{array}{l}\text { "Randomization was performed by an independent } \\
\text { contract research organization that generated } \\
\text { randomisation assignments" (from Gendreau 2005) }\end{array}$ \\
\hline $\begin{array}{l}\text { Allocation } \\
\text { concealment } \\
\text { (selection bias) }\end{array}$ & Unclear risk & Not described \\
\hline $\begin{array}{l}\text { Blinding of } \\
\text { participants and } \\
\text { personnel } \\
\text { (performance } \\
\text { bias) } \\
\text { All outcomes }\end{array}$ & Low risk & $\begin{array}{l}\text { "Blinding was rigorously maintained, as all patients } \\
\text { took capsules morning and evening that were } \\
\text { visually identical" (from Gendreau 2005) }\end{array}$ \\
\hline $\begin{array}{l}\text { Blinding of } \\
\text { outcome } \\
\text { assessment } \\
\text { (detection bias) } \\
\text { All outcomes }\end{array}$ & Low risk & $\begin{array}{l}\text { "Patients and investigators remained blinded to } \\
\text { patients' treatment allocation" (from Gendreau } \\
\text { 2005) }\end{array}$ \\
\hline $\begin{array}{l}\text { Incomplete } \\
\text { outcome data } \\
\text { (attrition bias) } \\
\text { All outcomes }\end{array}$ & High risk & Last observation carried forward for all analyses \\
\hline $\begin{array}{l}\text { Selective } \\
\text { reporting } \\
\text { (reporting bias) }\end{array}$ & Low risk & $\begin{array}{l}\text { All relevant outcomes in methods were reported in } \\
\text { some way, although not necessarily as our preferred } \\
\text { outcome }\end{array}$ \\
\hline Size & High risk & All groups $\leq 51$ \\
\hline
\end{tabular}

ACR: American College of Rheumatology; BDI: Beck Depression Inventory, BOCF: baseline observation carried forward; DB: double-blinding; FIQ: fibromyalgia impact questionnaire; FM: fibromyalgia; h: hour; NSAIDS: non-steroidal antiinflammatory drugs; PCS: physical component summary; PED: patient experience diary; PGIC: patient global impression of change; PI: pain intensity; R: randomisation; VAS: visual analogue scale; W: withdrawals 


\section{Characteristics of excluded studies [ordered by study ID]}

\begin{tabular}{ll}
\hline Study & Reason for exclusion \\
\hline Branco 2011 & Participants from Branco 2010 re-randomised for extension study \\
\hline Goldenberg 2010 & $\begin{array}{l}\text { No placebo control (trial followed a 6-month lead-in study, where placebo controls were re- } \\
\text { randomised to treatment with milnacipran) }\end{array}$ \\
\hline NCT00797797 & Open-label study \\
\hline
\end{tabular}

\section{Characteristics of ongoing studies [ordered by study ID]}

NCT01225068

\begin{tabular}{ll}
\hline Trial name or title & $\begin{array}{l}\text { An exploratory randomized placebo controlled trial of milnacipran in patients with chronic } \\
\text { neuropathic low back pain }\end{array}$ \\
\hline Methods & Randomised, double blind, placebo-controlled, parallel-group, 6 weeks \\
\hline Participants & $\begin{array}{l}\text { History of low back pain for a minimum of } 6 \text { months with radiation to leg or buttocks VAS pain } \\
>50 / 100 \\
\text { Age } 18 \text { to } 70 \text { years }\end{array}$ \\
\hline Interventions & $\begin{array}{l}\text { Titration to } 2 \times 50 \text { mg milnacipran daily, or placebo } \\
\text { Option to increase to 2 } \times 100 \text { mg daily after 2 weeks }\end{array}$ \\
\hline Outcomes & $\begin{array}{l}\text { Effect size of pain outcome measures (several pain outcome measures in the form of surveys } \\
\text { will be used) }\end{array}$ \\
$\begin{array}{l}\text { Visual analogue pain scale, Brief Pain Index, McGill Pain Questionnaire, physical activity } \\
\text { measurement, adverse events }\end{array}$ \\
\hline Starting date & October 2010 \\
\hline Contact information & Danielle Barkema (d-barkema @ northwestern.edu) \\
\hline Notes & Recruiting (March 2011) \\
\hline
\end{tabular}

NCT01288937

\begin{tabular}{ll}
\hline Trial name or title & $\begin{array}{l}\text { Aplacebo controlled, randomized, double blind trial of milnacipran for the treatment of } \\
\text { idiopathic neuropathy pain }\end{array}$ \\
\hline Methods & Randomised, double-blind, placebo-controlled, parallel-group, 11 weeks \\
\hline Participants & $\begin{array}{l}\text { Patients with signs and symptoms of a peripheral neuropathy, with either abnormal nerve } \\
\text { conductions or abnormal epidermal nerve fibre density with neuropathic pain } \\
\text { Age } 18 \text { to } 80 \text { years } \\
\text { Pain } \geq 6 \text { months }\end{array}$ \\
\hline Interventions & Titration to 2 $\times 50$ mg milnacipran daily, or placebo \\
\hline Outcomes & $\begin{array}{l}\text { Change in average 11-point Likert pain scale (0 to 10) } \\
\text { Change in Rand-36 Item Quality of Life Scale }\end{array}$ \\
\hline Starting date & November 2010 \\
\hline Contact information & Thomas H Brannagan, MD \\
\hline Notes & Recruiting (August 2011) \\
\hline
\end{tabular}

VAS: visual analogue scale 
DATA AND ANALYSES

\section{Comparison 1}

Milnacipran $100 \mathrm{mg} /$ day versus placebo

\begin{tabular}{|c|c|c|c|c|}
\hline $\begin{array}{l}\text { Outcome or subgroup } \\
\text { title }\end{array}$ & No. of studies & No. of participants & Statistical method & Effect size \\
\hline 1 At least $30 \%$ pain relief & 2 & 1825 & $\begin{array}{l}\text { Risk Ratio (M-H, Fixed, } \\
\text { 95\% CI) }\end{array}$ & $1.39[1.23,1.58]$ \\
\hline $\begin{array}{l}2 \text { PGIC 'much improved' } \\
\text { or 'very much improved' }\end{array}$ & 2 & 1825 & $\begin{array}{l}\text { Risk Ratio (M-H, Fixed, } \\
95 \% \mathrm{CI})\end{array}$ & $1.52[1.32,1.74]$ \\
\hline 3 Composite 1 & 3 & 2272 & $\begin{array}{l}\text { Risk Ratio (M-H, Fixed, } \\
\text { 95\% CI) }\end{array}$ & $1.46[1.25,1.71]$ \\
\hline 4 Composite 2 & 3 & 2272 & $\begin{array}{l}\text { Risk Ratio (M-H, Fixed, } \\
\text { 95\% CI) }\end{array}$ & $1.73[1.41,2.14]$ \\
\hline $\begin{array}{l}5 \text { At least one adverse } \\
\text { event }\end{array}$ & 3 & 2272 & $\begin{array}{l}\text { Risk Ratio (M-H, Fixed, } \\
\text { 95\% CI) }\end{array}$ & $1.10[1.06,1.14]$ \\
\hline 6 Serious adverse events & 3 & 2272 & $\begin{array}{c}\text { Risk Ratio (M-H, Fixed, } \\
\text { 95\% CI) }\end{array}$ & $0.88[0.45,1.73]$ \\
\hline $\begin{array}{l}7 \text { Individual adverse } \\
\text { events }\end{array}$ & 3 & & $\begin{array}{l}\text { Risk Ratio (M-H, Fixed, } \\
\text { 95\% CI) }\end{array}$ & Subtotals only \\
\hline 7.1 Nausea & 3 & 2272 & $\begin{array}{c}\text { Risk Ratio (M-H, Fixed, } \\
95 \% \text { CI) }\end{array}$ & $1.73[1.50,1.98]$ \\
\hline 7.2 Headache & 3 & 2272 & $\begin{array}{l}\text { Risk Ratio (M-H, Fixed, } \\
\text { 95\% CI) }\end{array}$ & $1.21[1.00,1.46]$ \\
\hline 7.3 Constipation & 3 & 2272 & $\begin{array}{l}\text { Risk Ratio (M-H, Fixed, } \\
95 \% \text { CI) }\end{array}$ & $4.12[2.97,5.71]$ \\
\hline 7.4 Hot flush & 3 & 2272 & $\begin{array}{l}\text { Risk Ratio (M-H, Fixed, } \\
\text { 95\% CI) }\end{array}$ & $4.25[2.86,6.31]$ \\
\hline 7.5 Dizziness & 3 & 2272 & $\begin{array}{l}\text { Risk Ratio (M-H, Fixed, } \\
\text { 95\% CI) }\end{array}$ & $2.02[1.49,2.74]$ \\
\hline 7.6 Palpitations & 3 & 2272 & $\begin{array}{l}\text { Risk Ratio (M-H, Fixed, } \\
95 \% \mathrm{CI})\end{array}$ & $3.02[1.97,4.63]$ \\
\hline 7.7 Insomnia & 3 & 2272 & $\begin{array}{c}\text { Risk Ratio (M-H, Fixed, } \\
\text { 95\% CI) }\end{array}$ & $1.19[0.92,1.53]$ \\
\hline $\begin{array}{l}7.8 \text { Increased heart rate/ } \\
\text { tachycardia }\end{array}$ & 3 & 2272 & $\begin{array}{l}\text { Risk Ratio (M-H, Fixed, } \\
\text { 95\% CI) }\end{array}$ & $5.42[2.87,10.25]$ \\
\hline 7.9 Hyperhidrosis & 3 & 2272 & $\begin{array}{l}\text { Risk Ratio (M-H, Fixed, } \\
\text { 95\% CI) }\end{array}$ & $5.09[3.05,8.50]$ \\
\hline 7.10 Diarrhoea & 3 & 2272 & $\begin{array}{c}\text { Risk Ratio (M-H, Fixed, } \\
\text { 95\% CI) }\end{array}$ & $0.83[0.59,1.18]$ \\
\hline 7.11 Vomiting & 2 & 1247 & $\begin{array}{l}\text { Risk Ratio (M-H, Fixed, } \\
\text { 95\% CI) }\end{array}$ & $2.70[1.44,5.05]$ \\
\hline 7.12 Sinusitis & 2 & 1247 & $\begin{array}{l}\text { Risk Ratio (M-H, Fixed, } \\
\text { 95\% CI) }\end{array}$ & $0.92[0.58,1.45]$ \\
\hline 7.13 Hypertension & 2 & 1825 & $\begin{array}{l}\text { Risk Ratio (M-H, Fixed, } \\
\text { 95\% CI) }\end{array}$ & $4.71[2.47,8.96]$ \\
\hline 7.14 Fatigue & 2 & 1825 & $\begin{array}{l}\text { Risk Ratio (M-H, Fixed, } \\
\text { 95\% CI) }\end{array}$ & $1.27[0.86,1.86]$ \\
\hline 7.15 URTI & 2 & 1472 & $\begin{array}{l}\text { Risk Ratio (M-H, Fixed, } \\
\text { 95\% CI) }\end{array}$ & $0.90[0.59,1.37]$ \\
\hline 8 All-cause withdrawals & 3 & 2272 & $\begin{array}{c}\text { Risk Ratio (M-H, Fixed, } \\
\text { 95\% CI) }\end{array}$ & $1.14[1.02,1.29]$ \\
\hline $\begin{array}{l}9 \text { Lack of efficacy } \\
\text { withdrawals }\end{array}$ & 3 & 2272 & $\begin{array}{c}\text { Risk Ratio (M-H, Fixed, } \\
95 \% \mathrm{CI})\end{array}$ & $0.75[0.57,1.00]$ \\
\hline
\end{tabular}




\begin{tabular}{lcccc}
\hline $\begin{array}{l}\text { Outcome or subgroup } \\
\text { title }\end{array}$ & No. of studies & No. of participants & Statistical method & Effect size \\
\hline $\begin{array}{l}\text { 10 Adverse event } \\
\text { withdrawals }\end{array}$ & 3 & 2272 & $\begin{array}{c}\text { Risk Ratio (M-H, Fixed, } \\
95 \% \text { CI })\end{array}$ & $1.61[1.32,1.97]$ \\
\hline
\end{tabular}

Comparison 2

Milnacipran 200 mg/day versus placebo

\begin{tabular}{|c|c|c|c|c|}
\hline $\begin{array}{l}\text { Outcome or subgroup } \\
\text { title }\end{array}$ & No. of studies & No. of participants & Statistical method & Effect size \\
\hline 1 At least $30 \%$ pain relief & 3 & 1798 & $\begin{array}{c}\text { Risk Ratio (M-H, Fixed, } \\
95 \% \text { CI) }\end{array}$ & $1.35[1.18,1.54]$ \\
\hline $\begin{array}{l}2 \text { PGIC 'much improved' } \\
\text { or 'very much improved' }\end{array}$ & 2 & 1673 & $\begin{array}{c}\text { Risk Ratio (M-H, Fixed, } \\
95 \% \mathrm{CI})\end{array}$ & $1.57[1.34,1.83]$ \\
\hline 3 Composite 1 & 3 & 2337 & $\begin{array}{c}\text { Risk Ratio (M-H, Fixed, } \\
95 \% \mathrm{CI})\end{array}$ & $1.91[1.59,2.29]$ \\
\hline 4 Composite 2 & 2 & 1461 & $\begin{array}{l}\text { Risk Ratio (M-H, Fixed, } \\
95 \% \mathrm{CI})\end{array}$ & $1.61[1.21,2.13]$ \\
\hline $\begin{array}{l}5 \text { At least one adverse } \\
\text { event }\end{array}$ & 3 & 2338 & $\begin{array}{c}\text { Risk Ratio (M-H, Fixed, } \\
95 \% \mathrm{CI})\end{array}$ & $1.10[1.06,1.15]$ \\
\hline 6 Serious adverse events & 4 & 2463 & $\begin{array}{c}\text { Risk Ratio (M-H, Fixed, } \\
95 \% \mathrm{CI})\end{array}$ & $0.91[0.52,1.60]$ \\
\hline 7 Individual adverse events & 3 & & $\begin{array}{c}\text { Risk Ratio (M-H, Fixed, } \\
95 \% \mathrm{CI})\end{array}$ & Subtotals only \\
\hline 7.1 Nausea & 3 & 2338 & $\begin{array}{c}\text { Risk Ratio (M-H, Fixed, } \\
95 \% \mathrm{CI})\end{array}$ & $2.37[2.00,2.80]$ \\
\hline 7.2 Headache & 3 & 2338 & $\begin{array}{c}\text { Risk Ratio (M-H, Fixed, } \\
95 \% \mathrm{CI})\end{array}$ & $1.35[1.10,1.64]$ \\
\hline 7.3 Constipation & 3 & 2338 & $\begin{array}{c}\text { Risk Ratio (M-H, Fixed, } \\
95 \% \mathrm{CI})\end{array}$ & $5.01[3.46,7.24]$ \\
\hline 7.4 Hot flush & 3 & 2338 & $\begin{array}{c}\text { Risk Ratio (M-H, Fixed, } \\
95 \% \mathrm{CI})\end{array}$ & $6.71[4.06,11.09]$ \\
\hline 7.5 Dizziness & 3 & 2338 & $\begin{array}{c}\text { Risk Ratio (M-H, Fixed, } \\
95 \% \mathrm{CI})\end{array}$ & $1.63[1.22,2.18]$ \\
\hline 7.6 Palpitations & 3 & 2288 & $\begin{array}{c}\text { Risk Ratio (M-H, Fixed, } \\
95 \% \mathrm{CI})\end{array}$ & $3.38[2.17,5.29]$ \\
\hline 7.7 Insomnia & 3 & 2338 & $\begin{array}{c}\text { Risk Ratio (M-H, Fixed, } \\
95 \% \mathrm{CI})\end{array}$ & $1.45[1.11,1.89]$ \\
\hline $\begin{array}{l}7.8 \text { Increased heart rate/ } \\
\text { tachycardia }\end{array}$ & 3 & 2338 & $\begin{array}{l}\text { Risk Ratio (M-H, Fixed, } \\
95 \% \mathrm{CI})\end{array}$ & $6.81[3.54,13.13]$ \\
\hline 7.9 Hyperhidrosis & 2 & 1461 & $\begin{array}{c}\text { Risk Ratio (M-H, Fixed, } \\
95 \% \mathrm{CI})\end{array}$ & $5.18[2.67,10.02]$ \\
\hline 7.10 Diarrhoea & 2 & 1461 & $\begin{array}{c}\text { Risk Ratio (M-H, Fixed, } \\
95 \% \mathrm{CI})\end{array}$ & $0.63[0.40,0.99]$ \\
\hline 7.11 Vomiting & 3 & 2338 & $\begin{array}{c}\text { Risk Ratio (M-H, Fixed, } \\
95 \% \mathrm{CI})\end{array}$ & $2.30[1.48,3.58]$ \\
\hline 7.12 Sinusitis & 2 & 1461 & $\begin{array}{c}\text { Risk Ratio (M-H, Fixed, } \\
95 \% \mathrm{CI})\end{array}$ & $1.14[0.76,1.70]$ \\
\hline 8 All-cause withdrawals & 4 & 2416 & $\begin{array}{l}\text { Risk Ratio (M-H, Fixed, } \\
95 \% \mathrm{CI})\end{array}$ & $1.38[1.22,1.57]$ \\
\hline $\begin{array}{l}9 \text { Lack of efficacy } \\
\text { withdrawals }\end{array}$ & 4 & 2462 & $\begin{array}{c}\text { Risk Ratio (M-H, Fixed, } \\
95 \% \mathrm{CI})\end{array}$ & $0.66[0.51,0.87]$ \\
\hline
\end{tabular}




\section{Analysis 1.3. Comparison 1 Milnacipran $100 \mathrm{mg} /$ day versus placebo, Outcome 3 Composite 1}

Review: Milnacipran for neuropathic pain and fibromyalgia in adults

Comparison: 1 Milnacipran $100 \mathrm{mg} /$ day versus placebo

Outcome: 3 Composite 1

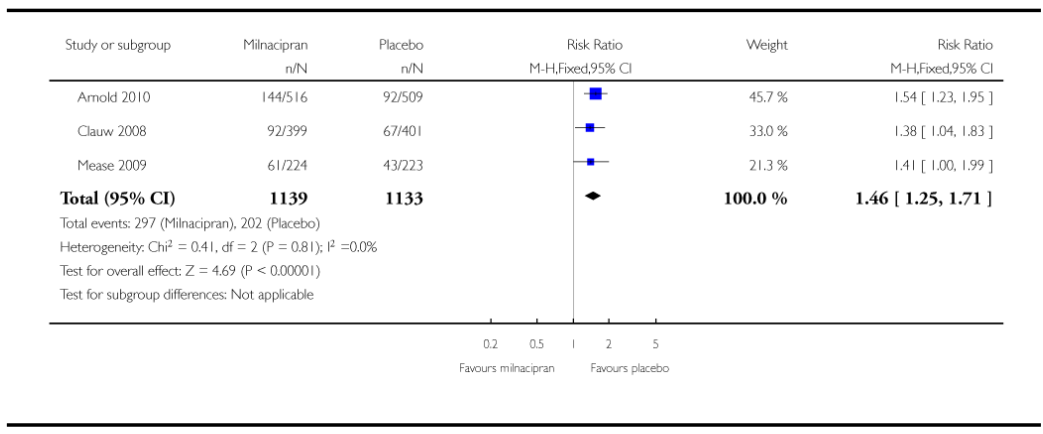

\section{Analysis 1.4. Comparison 1 Milnacipran $100 \mathrm{mg} /$ day versus placebo, Outcome 4 Composite 2}

Review: Milnacipran for neuropathic pain and fibromyalgia in adults

Comparison: 1 Milnacipran $100 \mathrm{mg} /$ day versus placebo

Outcome: 4 Composite 2

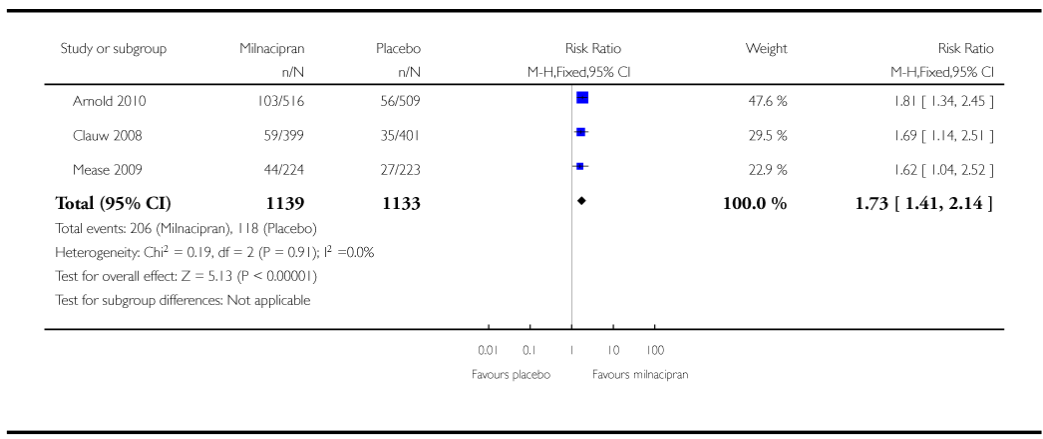

\section{Analysis 1.5. Comparison 1 Milnacipran $100 \mathrm{mg} /$ day versus placebo, Outcome 5 At least one adverse event}

Review: Milnacipran for neuropathic pain and fibromyalgia in adults

Comparison: 1 Milnacipran $100 \mathrm{mg} /$ day versus placebo 
Outcome: 5 At least one adverse event

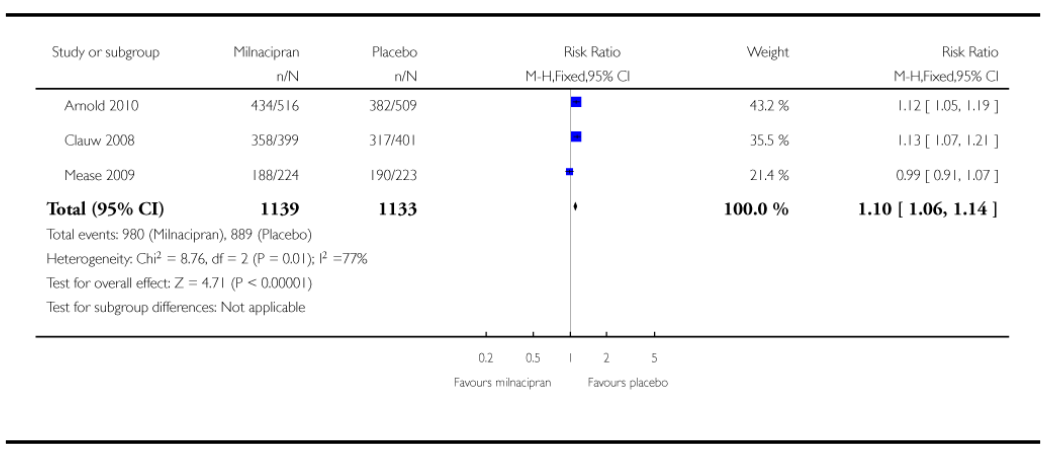

\section{Analysis 1.6. Comparison 1 Milnacipran $100 \mathrm{mg} /$ day versus placebo, Outcome 6 Serious adverse events}

Review: Milnacipran for neuropathic pain and fibromyalgia in adults

Comparison: 1 Milnacipran $100 \mathrm{mg} /$ day versus placebo

Outcome: 6 Serious adverse events

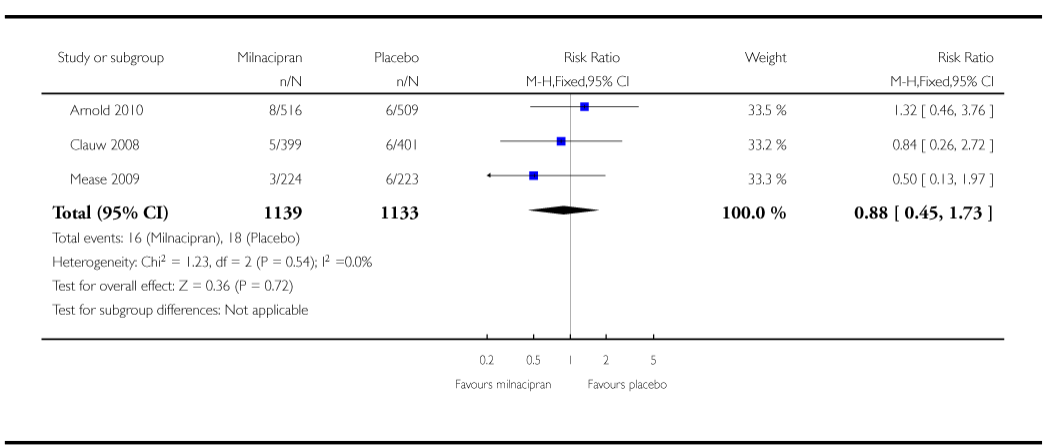

\section{Analysis 1.7. Comparison 1 Milnacipran $100 \mathrm{mg} /$ day versus placebo, Outcome 7 Individual adverse events}

Review: Milnacipran for neuropathic pain and fibromyalgia in adults

Comparison: 1 Milnacipran $100 \mathrm{mg} /$ day versus placebo

Outcome: 7 Individual adverse events 


\begin{tabular}{|c|c|c|c|c|c|}
\hline Study or subgroup & $\begin{array}{r}\text { Milnacipran } \\
\mathrm{n} / \mathrm{N}\end{array}$ & $\begin{array}{r}\text { Placebo } \\
n / N\end{array}$ & $\begin{array}{c}\text { Risk Ratio } \\
\text { M-H.Fixed,95\% C }\end{array}$ & Weight & $\begin{array}{r}\text { Risk Ratio } \\
\text { M-H.Fixed.95\% CI }\end{array}$ \\
\hline \multicolumn{6}{|l|}{ I Nausea } \\
\hline Amold 2010 & $189 / 516$ & 106,509 & 풀 & $46.3 \%$ & $1.76[1.43,2.16]$ \\
\hline Clauw 2008 & 137/399 & 77,401 & - & $33.3 \%$ & $1.79[1.40,2.28]$ \\
\hline Mease 2009 & 73/224 & $47 / 223$ & - & $20.4 \%$ & $1.55[1.13,2.12]$ \\
\hline Subtotal $(95 \% \mathrm{CI})$ & 1139 & 1133 & - & $100.0 \%$ & $1.73[1.50,1.98]$ \\
\hline \multicolumn{6}{|c|}{ Total events: 399 (Milinacipran), 230 (Placebo) } \\
\hline \multicolumn{6}{|c|}{ Heterogeneity $: \mathrm{Chi}^{2}=0.58, \mathrm{df}=2(\mathrm{P}=0.75) ; \mathrm{I}^{2}=0.0 \%$} \\
\hline \multicolumn{6}{|c|}{ Test for overall effect: $Z=7.64(P<0.00001)$} \\
\hline \multicolumn{6}{|l|}{2 Headache } \\
\hline Amold 2010 & $92 / 516$ & 80,509 & $=$ & $49.0 \%$ & $1.13[0.86,1.49]$ \\
\hline Clauw 2008 & 72/399 & $58: 401$ & $=$ & $35.2 \%$ & $1.25[0.91,1.71]$ \\
\hline Mease 2009 & 35/224 & 26,223 & - & $15.8 \%$ & $1.34[0.84,2.15]$ \\
\hline Subtotal $(95 \% \mathrm{CI})$ & 1139 & 1133 & - & $100.0 \%$ & $1.21[1.00,1.46]$ \\
\hline \multicolumn{6}{|c|}{ Total events: 199 (Milinacipran), 164 (Placebo) } \\
\hline \multicolumn{6}{|c|}{ Heterogeneity $\mathrm{Chi}^{2}=0.43, \mathrm{df}=2(\mathrm{P}=0.81) ; \mathrm{I}^{2}=0.0 \%$} \\
\hline \multicolumn{6}{|c|}{ Test for overall effect: $Z=1.94(P=0.052)$} \\
\hline \multicolumn{6}{|l|}{3 Constipation } \\
\hline Amold 2010 & $76 / 516$ & 20.509 & $=$ & $47.8 \%$ & $3.75[2.33,6.04]$ \\
\hline Clauw 2008 & $57 / 399$ & 16:401 & - & $37.9 \%$ & $3.58[209.6 .12]$ \\
\hline Mease 2009 & $41 / 224$ & $6 / 223$ & $\rightarrow$ & $14.3 \%$ & $6.80[2.95,15.70]$ \\
\hline Subtotal $(95 \% \mathrm{CI})$ & 1139 & 1133 & - & $100.0 \%$ & $4.12[2.97,5.71]$ \\
\hline \multicolumn{6}{|c|}{ Total events: 174 (Millacipran), 42 (Placebo) } \\
\hline \multirow{2}{*}{\multicolumn{6}{|c|}{ Heterogeneity. $C \mathrm{Ch}^{2}=1.79, \mathrm{df}=2(\mathrm{P}=0.41) ; 1^{2}=0.0 \%$}} \\
\hline \multicolumn{3}{|c|}{ Test for coveral effect: $Z=8.49(P<0.00001)$} & & & \\
\hline \multicolumn{6}{|l|}{4 Hot flush } \\
\hline Arnold 2010 & $56 / 516$ & $18: 509$ & - & $62.2 \%$ & $3.07[1.83,5.15]$ \\
\hline Clauw 2008 & $46 / 399$ & 5,401 & $\longrightarrow$ & $17.1 \%$ & $9.25[3.71,23.03]$ \\
\hline Mease 2009 & $22 / 224$ & 6:2223 & $\because$ & $20.6 \%$ & $3.65[1.51,8.83]$ \\
\hline Subtotal $(95 \% \mathrm{CI})$ & 1139 & 1133 & - & $100.0 \%$ & $4.25[2.86,6.31]$ \\
\hline \multicolumn{6}{|c|}{ Total events: 124 (Milnacipran), 29 (Placebo) } \\
\hline Heterogeneity. $\mathrm{Chi}^{2}=4.42$ & $2(P=0.11) ; 1$ & & & & \\
\hline
\end{tabular}




\begin{tabular}{|c|c|c|c|c|c|}
\hline Study or subgroup & $\begin{array}{c}\text { Milaraipran } \\
\mathrm{nNN}\end{array}$ & $\begin{aligned} P l a c e b o \\
n / N\end{aligned}$ & $\begin{array}{l}\text { Reck Ratio } \\
\text { M-H.Fixed,95\% CI }\end{array}$ & Weight & \multirow[t]{2}{*}{$\begin{array}{r}\text { Risk Ratio } \\
\text { M-HFixed,95\% Cl }\end{array}$} \\
\hline \multirow{2}{*}{\multicolumn{6}{|c|}{ Test for overal effect: $Z=7.17(\mathbb{P}<0.00001)$}} \\
\hline & & & & & \\
\hline Amold 2010 & $\$ 4 / 516$ & 26,509 & 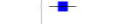 & $45.0 \%$ & $205[1.30,3.22]$ \\
\hline Claum 2008 & 381399 & 177401 & - & $292 \%$ & $225[1.29,3.91]$ \\
\hline Mease 2009 & 261224 & $15 / 223$ & - & $25.8 \%$ & $1.73[0.94,3.17]$ \\
\hline Subtotal $(95 \% \mathrm{CI})$ & 1139 & 1133 & - & $100.0 \%$ & $2.02[1.49,2.74]$ \\
\hline \multirow{3}{*}{\multicolumn{6}{|c|}{ 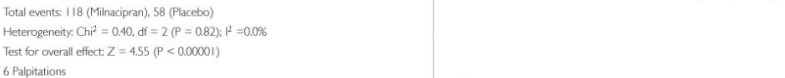 }} \\
\hline & & & & & \\
\hline & & & & & \\
\hline Amoks 2010 & 38516 & 15,509 & $=$ & $558 \%$ & $250[1,39,4.49]$ \\
\hline Clauw 2008 & 261399 & 10/401 & $\rightarrow$ & $368 \%$ & $2.61[1.28,5.35]$ \\
\hline Mease 2009 & 18224 & $2 / 223$ & $\longrightarrow$ & $7.4 \%$ & $8.96[2.10,38.16]$ \\
\hline Subtotal $(95 \% \mathrm{CI})$ & 1139 & 1133 & - & $100.0 \%$ & $3.02[1.97,4.63]$ \\
\hline \multirow{3}{*}{\multicolumn{6}{|c|}{ 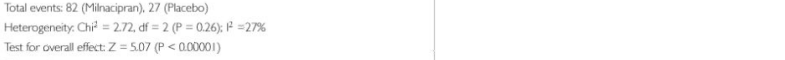 }} \\
\hline & & & & & \\
\hline \multirow{2}{*}{\multicolumn{4}{|c|}{7 Irsomnia }} & & \\
\hline & & $41 / 509$ & - & $420 \%$ & $1.23[0.833 .1 .82]$ \\
\hline Clane 2008 & $42 / 399$ & $42 / 401$ & $=$ & $42.7 \%$ & $1.01[0.67,1.51]$ \\
\hline Mease 2009 & $24 / 224$ & $15 / 223$ & $\rightarrow$ & $15.3 \%$ & $1.59[0.86,295]$ \\
\hline Subtotal $(95 \% \mathrm{CI})$ & 1139 & 1133 & $\leftarrow$ & $100.0 \%$ & $1.19[0.92,1.53]$ \\
\hline \multirow{4}{*}{\multicolumn{6}{|c|}{ 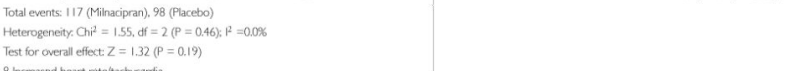 }} \\
\hline & & & & & \\
\hline & & & & & \\
\hline 8 increared heart ratet tach & & & & & \\
\hline Amold 2010 & 281516 & $5 / 509$ & $=$ & $45.6 \%$ & $5.52[2.15,14.19]$ \\
\hline Clauw 2008 & 201399 & 1/401 & $\longrightarrow$ & $9.0 \%$ & $20.10[2.71,149.05]$ \\
\hline Mease 2009 & 127224 & $5 / 223$ & $=$ & $45.4 \%$ & $239[0.86,6.67]$ \\
\hline \multirow{4}{*}{\multicolumn{6}{|c|}{ 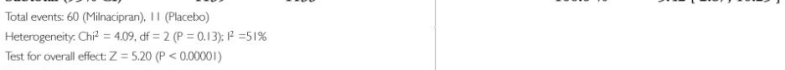 }} \\
\hline & & & & & \\
\hline & & & & & \\
\hline & & & & & \\
\hline \multicolumn{6}{|l|}{9 Hypertididosis } \\
\hline Antodid 2010 & $40: 516$ & 71509 & $\Rightarrow$ & $41,3 \%$ & $5.64\{255,1247\}$ \\
\hline Clauw 2008 & 251399 & $5 / 401$ & $\because$ & $29.3 \%$ & $5.03[1,94,13.00]$ \\
\hline Mease 2009 & 222224 & $5 / 223$ & $\because$ & $29,4 \%$ & $4.38[1.69,11.36]$ \\
\hline Subtotal $(95 \% \mathrm{CI})$ & 1139 & 1133 & - & $100.0 \%$ & $5.09[3.05,8.50]$ \\
\hline
\end{tabular}

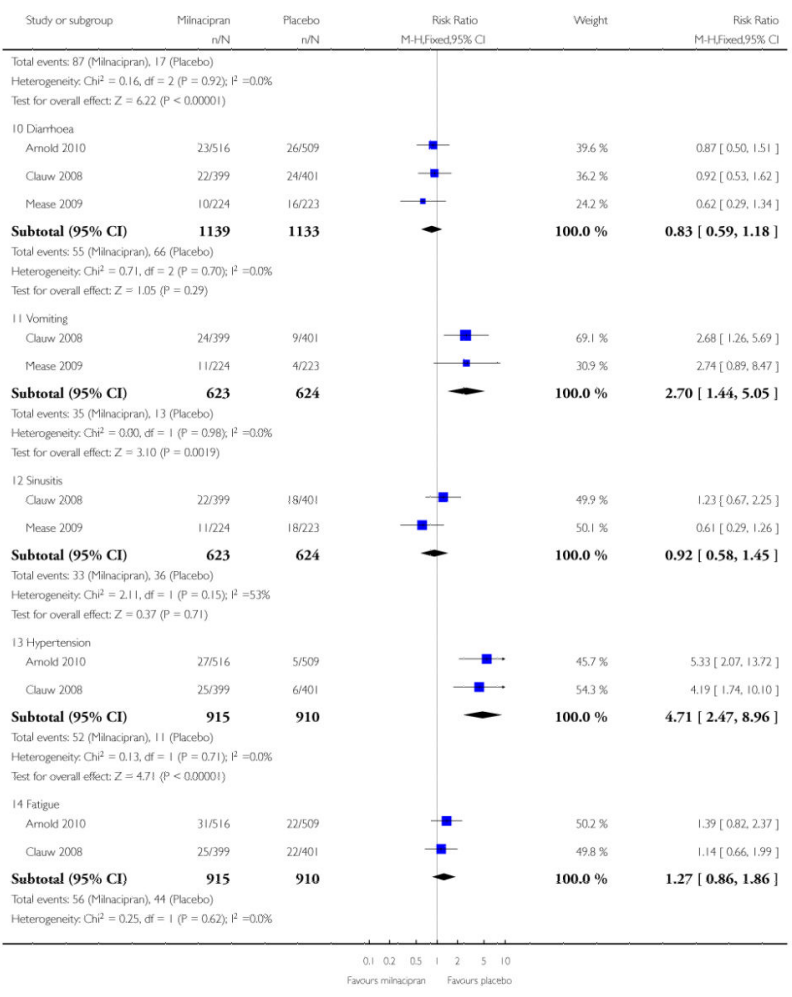

Cochrane Database Syst Rev. Author manuscript; available in PMC 2014 September 16. 


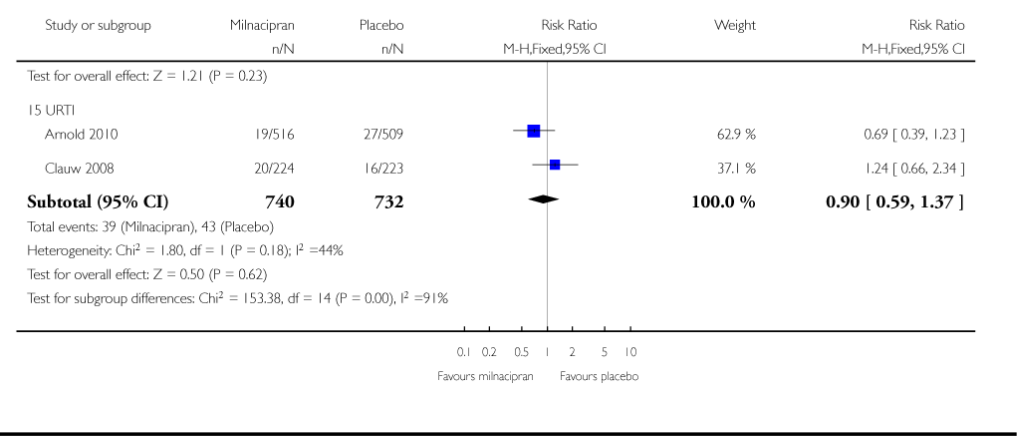

\section{Analysis 1.8. Comparison 1 Milnacipran $100 \mathrm{mg} /$ day versus placebo, Outcome 8 All-cause withdrawals}

Review: Milnacipran for neuropathic pain and fibromyalgia in adults

Comparison: 1 Milnacipran $100 \mathrm{mg} /$ day versus placebo

Outcome: 8 All-cause withdrawals

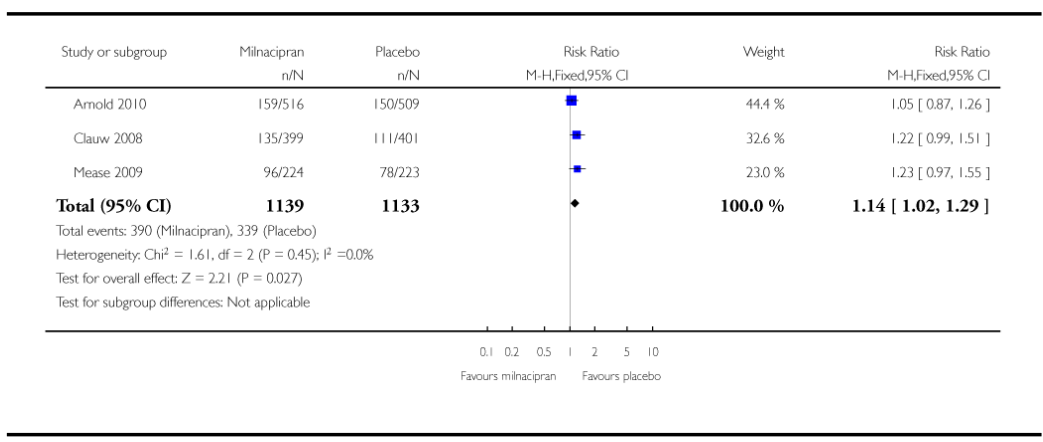

\section{Analysis 1.9. Comparison 1 Milnacipran $100 \mathrm{mg} /$ day versus placebo, Outcome 9 Lack of efficacy withdrawals}

Review: Milnacipran for neuropathic pain and fibromyalgia in adults

Comparison: 1 Milnacipran $100 \mathrm{mg} /$ day versus placebo

Outcome: 9 Lack of efficacy withdrawals 


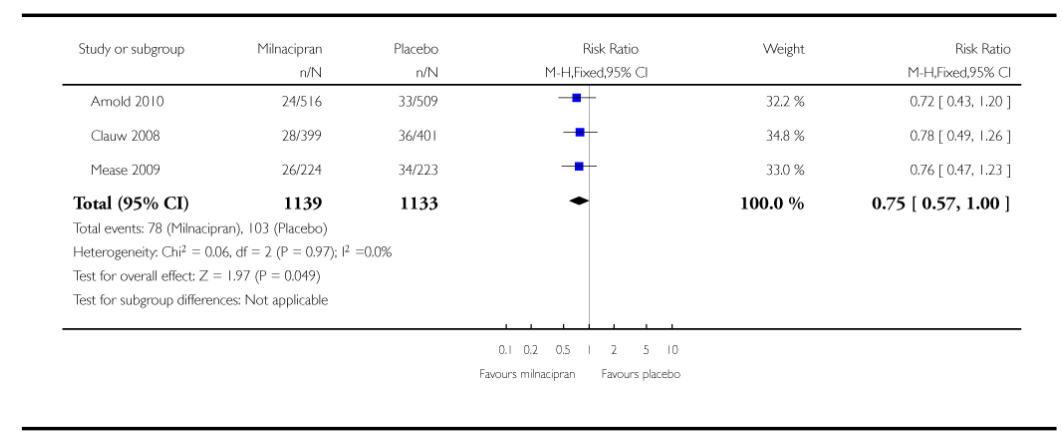

\section{Analysis 1.10. Comparison 1 Milnacipran $100 \mathrm{mg} /$ day versus placebo, Outcome 10 Adverse event withdrawals}

Review: Milnacipran for neuropathic pain and fibromyalgia in adults

Comparison: 1 Milnacipran $100 \mathrm{mg} /$ day versus placebo

Outcome: 10 Adverse event withdrawals

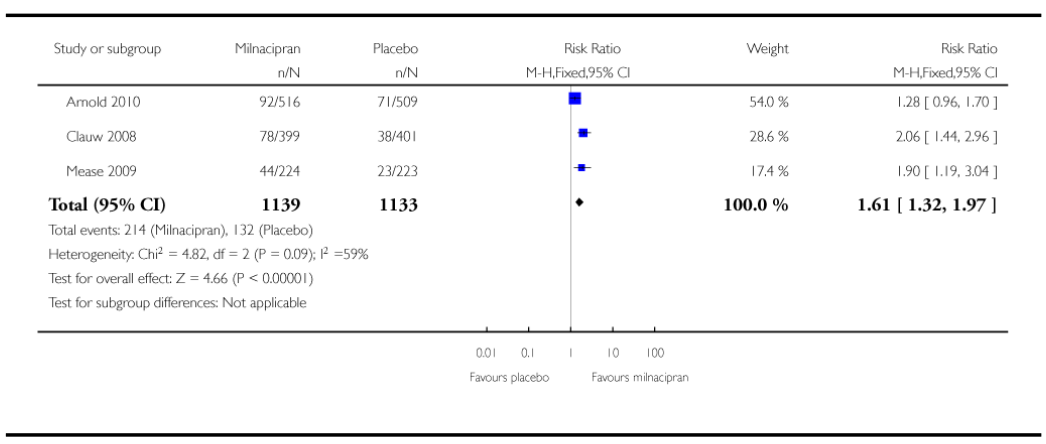

\section{Analysis 2.1. Comparison 2 Milnacipran $200 \mathrm{mg} /$ day versus placebo, Outcome 1 At least $30 \%$ pain relief}

Review: Milnacipran for neuropathic pain and fibromyalgia in adults

Comparison: 2 Milnacipran $200 \mathrm{mg} /$ day versus placebo

Outcome: 1 At least $30 \%$ pain relief 


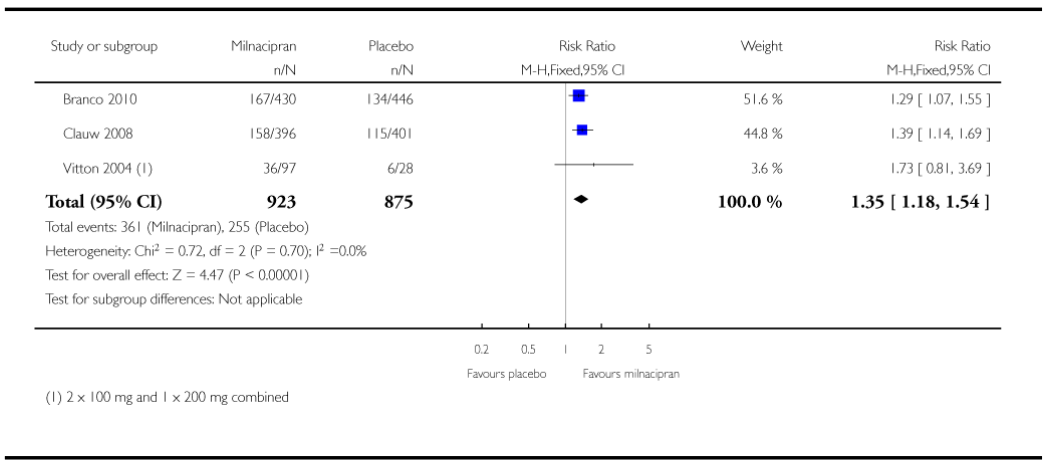

\section{Analysis 2.2. Comparison 2 Milnacipran $200 \mathrm{mg} /$ day versus placebo, Outcome 2 PGIC 'much improved' or 'very much improved'}

Review: Milnacipran for neuropathic pain and fibromyalgia in adults

Comparison: 2 Milnacipran $200 \mathrm{mg} /$ day versus placebo

Outcome: 2 PGIC 'much improved' or 'very much improved'

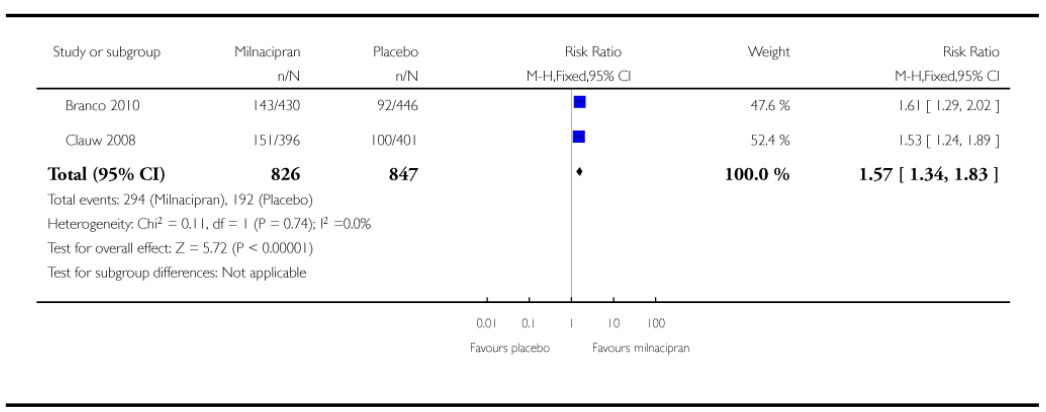

\section{Analysis 2.3. Comparison 2 Milnacipran $200 \mathrm{mg} /$ day versus placebo, Outcome 3 Composite 1}

Review: Milnacipran for neuropathic pain and fibromyalgia in adults

Comparison: 2 Milnacipran $200 \mathrm{mg} /$ day versus placebo

Outcome: 3 Composite 1 


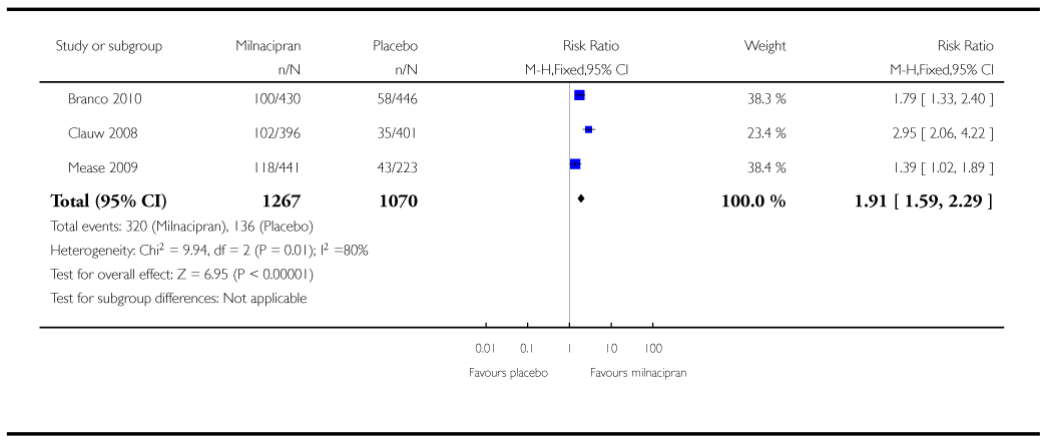

\section{Analysis 2.4. Comparison 2 Milnacipran $200 \mathrm{mg} /$ day versus placebo, Outcome 4 Composite 2}

Review: Milnacipran for neuropathic pain and fibromyalgia in adults

Comparison: 2 Milnacipran $200 \mathrm{mg} /$ day versus placebo

Outcome: 4 Composite 2

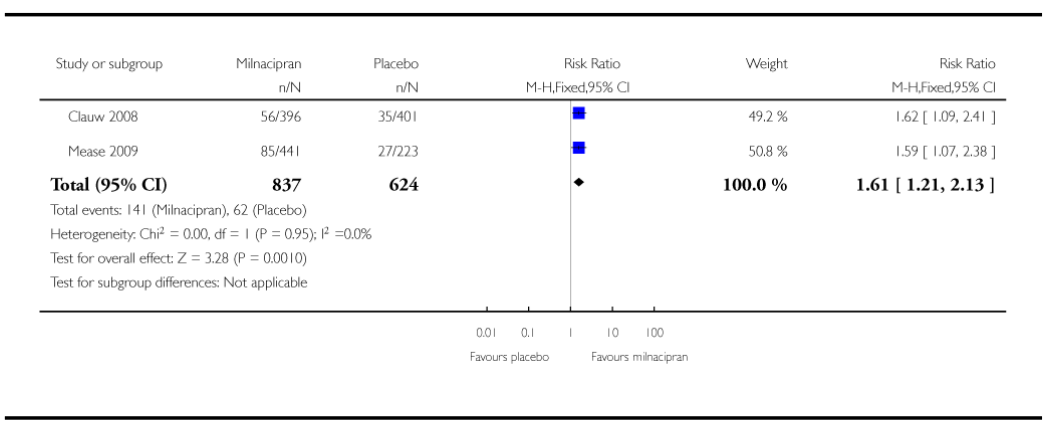

\section{Analysis 2.5. Comparison 2 Milnacipran $200 \mathrm{mg} /$ day versus placebo, Outcome 5 At least one adverse event}

Review: Milnacipran for neuropathic pain and fibromyalgia in adults

Comparison: 2 Milnacipran $200 \mathrm{mg} /$ day versus placebo

Outcome: 5 At least one adverse event 


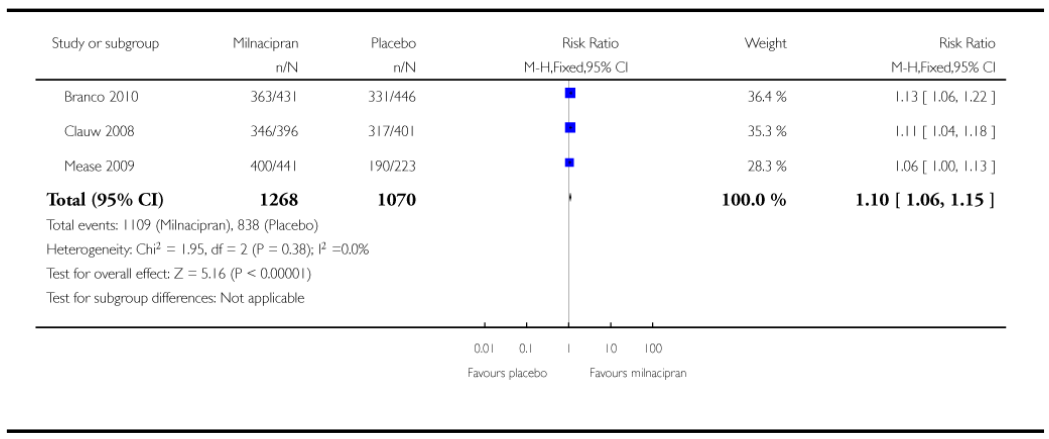

\section{Analysis 2.6. Comparison 2 Milnacipran $200 \mathrm{mg}$ /day versus placebo, Outcome 6 Serious adverse events}

Review: Milnacipran for neuropathic pain and fibromyalgia in adults

Comparison: 2 Milnacipran $200 \mathrm{mg} /$ day versus placebo

Outcome: 6 Serious adverse events

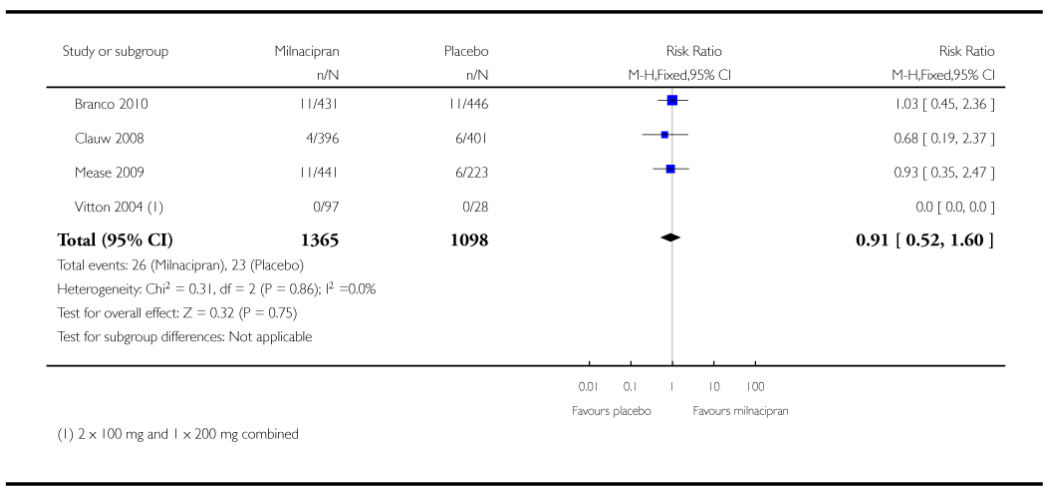

\section{Analysis 2.7. Comparison 2 Milnacipran $200 \mathrm{mg} /$ day versus placebo, Outcome 7 Individual adverse events}

Review: Milnacipran for neuropathic pain and fibromyalgia in adults

Comparison: 2 Milnacipran $200 \mathrm{mg} /$ day versus placebo

Outcome: 7 Individual adverse events 


\begin{tabular}{|c|c|c|c|c|c|}
\hline Study or subgroup & $\begin{array}{r}\text { Milinacipran } \\
\mathrm{n} / \mathrm{N}\end{array}$ & $\begin{array}{r}\text { Placebo } \\
\mathrm{n} / \mathrm{N}\end{array}$ & $\begin{array}{c}\text { Risk Ratio } \\
\text { M-H,Fixed,95\% Cl }\end{array}$ & Weight & $\begin{array}{r}\text { Risk Ratio } \\
\text { M-H,Fixed,95\% Cl }\end{array}$ \\
\hline \multicolumn{6}{|l|}{ I Nausea } \\
\hline Branco 2010 & |112/431 & $50 / 446$ & - & $30.4 \%$ & $2.32[1.71,3.15]$ \\
\hline Clauw 2008 & 149/1396 & $77 / 401$ & m & $47.4 \%$ & $1.96[1.55,2.48]$ \\
\hline Mease 2009 & 177/4441 & $27 / 223$ & * & $22.2 \%$ & $3.31[2.29,4.81]]-10$ \\
\hline Subtotal $(95 \% \mathrm{CI})$ & 1268 & 1070 & - & $100.0 \%$ & $2.37[2.00,2.80]$ \\
\hline \multicolumn{6}{|c|}{ Total events: 438 (Milinacipran). 154 (Placebo) } \\
\hline \multicolumn{6}{|c|}{ Heterogeneity. Chi' ${ }^{2}=5.62, \mathrm{df}=2(P=0.06) ;\left.\right|^{2}=64 \%$} \\
\hline \multicolumn{6}{|c|}{ Test for overall effect: $Z=10.02(P<0.00001)$} \\
\hline \multicolumn{6}{|l|}{2 Headache } \\
\hline Branco 2010 & 73/431 & $55 / 446$ & m & $37.0 \%$ & $1.37[0.99,1.90]$ \\
\hline Clauw 2008 & $70 / 396$ & $58 / 401$ & $=$ & $39.4 \%$ & $1.22[0.89,1.68]$ \\
\hline Mease 2009 & $78 / 441$ & $26 / 223$ & - & $23.6 \%$ & $1.52[1.00,2.29]$ \\
\hline Subtotal $(95 \% \mathrm{CI})$ & 1268 & 1070 & - & $100.0 \%$ & $1.35[1.10,1.64]$ \\
\hline \multicolumn{6}{|c|}{ Total events: 221 (Milinacipran), 139 (Placebo) } \\
\hline \multicolumn{6}{|c|}{ Heterogeneity. $C \mathrm{Ch}^{2}=0.69, \mathrm{df}=2(P=0.71) ; \mathrm{I}^{2}=0.0 \%$} \\
\hline \multicolumn{6}{|c|}{ Test for overall effect: $Z=2.94$ ( $P=0.0033)$} \\
\hline \multicolumn{6}{|l|}{3 Constipation } \\
\hline Branco 2010 & $54 / 431$ & $10 / 446$ & $\mp$ & $29.2 \%$ & $5.59[2.88,10.83]$ \\
\hline Clauw 2008 & $71 / 396$ & 16/401 & $=$ & $47.2 \%$ & $4.49[2.66,7.59]$ \\
\hline Mease 2009 & $63 / 441$ & $6 / 223$ & - & $23.7 \%$ & $5.31[2.33,12.08]$ \\
\hline Subtotal $(95 \% \mathrm{CI})$ & 1268 & 1070 & - & $100.0 \%$ & $5.01[3.46,7.24]$ \\
\hline \multicolumn{6}{|c|}{ Total events: 188 (Milnacipran), 32 (Placebo) } \\
\hline \multicolumn{6}{|c|}{ Heterogeneity; $C \mathrm{Ch}^{2}=0.29, \mathrm{df}=2(\mathrm{P}=0.87) ; \mathrm{L}^{2}=0.0 \%$} \\
\hline \multicolumn{6}{|c|}{ Test for overall effect: $Z=8.54(P<0.00001)$} \\
\hline \multicolumn{6}{|l|}{4 Hot flush } \\
\hline Branco 2010 & $30 / 431$ & $5 / 446$ & - & $27.5 \%$ & $6.21[2.43,15.85]$ \\
\hline Chuw 2008 & $58 / 396$ & $5 / 401$ & $=$ & $27.8 \%$ & $11.75[4.76,28.98]$ \\
\hline Mease 2009 & $46 / 441$ & $6 / 223$ & $=$ & $44.6 \%$ & $3.88[1.68,8.94]$ \\
\hline
\end{tabular}

\begin{tabular}{|c|c|c|c|c|c|}
\hline Stsddy or subgroup & 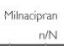 & $\begin{array}{l}\text { Placebo } \\
\text { nIN }\end{array}$ & $\begin{array}{l}\text { Risk Patio } \\
\text { M. HFoced,95\% CI }\end{array}$ & Weight & $\begin{array}{r}\text { Pisk Ratio } \\
\text { M.H. Fixed,95\% CI }\end{array}$ \\
\hline Subtotal $(95 \% \mathrm{CI})$ & 1268 & 1070 & - & $100.0 \%$ & $6.71[4.06,11.09]$ \\
\hline \multirow{2}{*}{\multicolumn{6}{|c|}{ 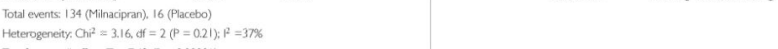 }} \\
\hline & & & & & \\
\hline \\
\hline Banco 2010 & 2443 & sores & $=$ & $476 \%$ & 15450873051 \\
\hline Cane 2008 & $36 / 396$ & 177401 & $\leftarrow$ & $241 \%$ & $214[127,3751$ \\
\hline Mease 2009 & 50/441 & $15 / 223$ & $=$ & $284 \%$ & $1.69[0.97,2.93]$ \\
\hline Subtotal $(95 \% \mathrm{CI})$ & 1268 & 1070 & - & $100.0 \%$ & $1.63[1.22,2.18]$ \\
\hline \multirow{2}{*}{\multicolumn{6}{|c|}{ Total events: 130 (Milinacipran), 66 (Placecos) }} \\
\hline \multirow{2}{*}{\multicolumn{6}{|c|}{ 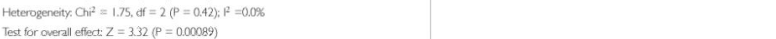 }} \\
\hline & & & & & \\
\hline \multicolumn{6}{|c|}{ 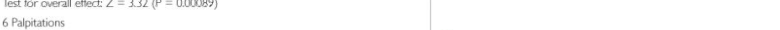 } \\
\hline Branco 2010 & 344431 & 13/446 & $=$ & $51.7 \%$ & $271[1.45,5.06]$ \\
\hline Claww 2008 & $30 / 346$ & 10/401 & - & $375 \%$ & $3.48[1,72,701]$ \\
\hline Mease 2009 & $25 / 441$ & 2023 & $\rightarrow-$ & $108 \%$ & $6.32[151.26,45]$ \\
\hline Subtotal $(95 \% \mathrm{CI})$ & 1218 & 1070 & - & $100.0 \%$ & $3.38[2.17,5.29]$ \\
\hline \multicolumn{6}{|c|}{ Total events: 89 (Mirracipran), 25 (Placebos) } \\
\hline \multicolumn{6}{|c|}{ 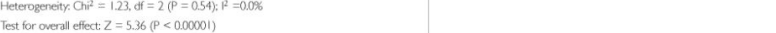 } \\
\hline \multicolumn{6}{|l|}{7 insomria } \\
\hline Branco 2010 & 33/431 & $24 / 446$ & $=$ & $277 \%$ & $1.42[086.237]$ \\
\hline Casw 2008 & 62336 & 42401 & $=$ & $490 \%$ & $1.49[1.04,2.16]$ \\
\hline Mease 20069 & $41 / 441$ & $15 / 223$ & - & $234 \%$ & $1.38[0.78,244]$ \\
\hline Subtotal $(95 \% \mathrm{CI})$ & 1268 & 1070 & - & $100.0 \%$ & $1.45[1.11,1.89]$ \\
\hline \multirow{3}{*}{\multicolumn{6}{|c|}{ 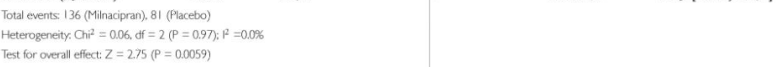 }} \\
\hline & & & & & \\
\hline & & & & & \\
\hline \multicolumn{6}{|c|}{8 increased heart rateteftctycardia } \\
\hline Branco 2010 & $29 / 431$ & $3 / 446$ & - & $279 \%$ & $10.00[3.07,3260]$ \\
\hline Clauw 2008 & 211396 & $1 / 401$ & 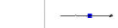 & $9.4 \%$ & $21.27[2.87,15733]$ \\
\hline Mease 2009 & 32/441 & $5 / 223$ & $=$ & $628 \%$ & $324[1.28 .8 .19]$ \\
\hline Subtotal $(95 \% \mathrm{CI})$ & 1268 & 1070 & - & $100.0 \%$ & $6.81[3.54,13.13]$ \\
\hline \multirow{2}{*}{\multicolumn{6}{|c|}{ Total everts B2 (Milinacipan), 9 (Placelobo) }} \\
\hline & & & & & \\
\hline \multirow{2}{*}{\multicolumn{6}{|c|}{ Test for overall effect $Z=5.73(P<0.00001)$}} \\
\hline 9 Hypechidossis & & & & & \\
\hline Clauw 2008 & 23/396 & $5 / 401$ & $=$ & $428 \%$ & $4.66[1.79,12.13]$ \\
\hline Mease 2009 & $55 / 441$ & $5 / 223$ & $=$ & $572 \%$ & $5.56[2.26,13.70]$ \\
\hline
\end{tabular}




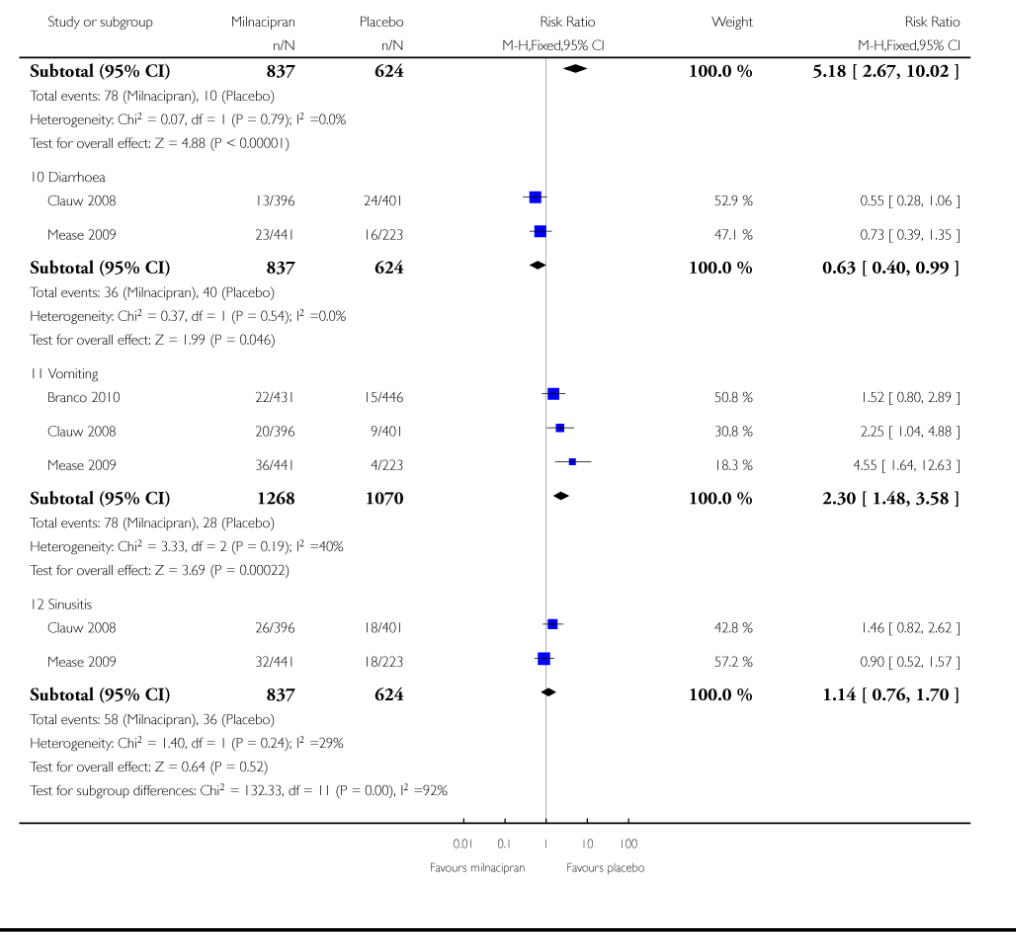

\section{Analysis 2.8. Comparison 2 Milnacipran $200 \mathrm{mg} /$ day versus placebo, Outcome 8 All-cause withdrawals}

Review: Milnacipran for neuropathic pain and fibromyalgia in adults

Comparison: 2 Milnacipran $200 \mathrm{mg} /$ day versus placebo

Outcome: 8 All-cause withdrawals

\begin{tabular}{|c|c|c|c|c|c|}
\hline Study or subgroup & $\begin{array}{r}\text { Milinacipran } \\
\mathrm{n} / \mathrm{N}\end{array}$ & $\begin{array}{r}\text { Placebo } \\
\mathrm{n} / \mathrm{N}\end{array}$ & $\begin{array}{c}\text { Risk Ratio } \\
\text { M-H,Fixed,95\% CI }\end{array}$ & Weight & $\begin{array}{r}\text { Risk Ratio } \\
\text { M-H,Fixed,95\% } \\
\end{array}$ \\
\hline Branco 2010 & $119 / 430$ & $72 / 446$ & $\div$ & $24.1 \%$ & $1.71[1.32,2.23]$ \\
\hline Clauw 2008 & $139 / 396$ & $111 / 401$ & 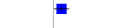 & $37.6 \%$ & $1.27[1.03,1.56]$ \\
\hline Mease 2009 & $202 / 441$ & $78 / 223$ & 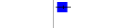 & $35.3 \%$ & $1.31[1.07,1.61]$ \\
\hline Vitton 2004 (I) & $14 / 51$ & $7 / 28$ & $\square$ & $3.1 \%$ & $1.10[0.50,2.40]$ \\
\hline $\begin{array}{l}\text { Total }(\mathbf{9 5 \%} \mathbf{C I}) \\
\text { Total events: } 474 \text { (Mil } \\
\text { Heterogeneity: Chi' } \\
\text { Test for overall effect } \\
\text { Test for subgroup diff }\end{array}$ & $\begin{array}{c}1318 \\
268 \text { (Placebo) } \\
=3(\mathrm{P}=0.27) \\
(\mathrm{P}<0.0000) \\
\text { Not applicable }\end{array}$ & 1098 & - & $100.0 \%$ & $1.38[1.22,1.57]$ \\
\hline
\end{tabular}

(1) $2 \times 100 \mathrm{mg}$ and $1 \times 200 \mathrm{mg}$ combined 


\section{Analysis 2.9. Comparison 2 Milnacipran $200 \mathrm{mg} /$ day versus placebo, Outcome 9 Lack of efficacy withdrawals}

Review: Milnacipran for neuropathic pain and fibromyalgia in adults

Comparison: 2 Milnacipran $200 \mathrm{mg} /$ day versus placebo

Outcome: 9 Lack of efficacy withdrawals

\begin{tabular}{|c|c|c|c|c|c|}
\hline Study or subgroup & $\begin{array}{r}\text { Milnacipran } \\
n / N\end{array}$ & $\begin{array}{r}\text { Placebo } \\
\mathrm{n} / \mathrm{N}\end{array}$ & $\begin{array}{c}\text { Risk Ratio } \\
\text { M-H,Fixed,95\% Cl }\end{array}$ & Weight & $\begin{array}{r}\text { Risk Ratio } \\
\text { M-H,Fixed,95\% CI }\end{array}$ \\
\hline Branco 2010 & $24 / 430$ & $31 / 446$ & - & $25.5 \%$ & $0.80[0.48,1.35]$ \\
\hline Clauw 2008 & 19/396 & $36 / 401$ & $=$ & $30.0 \%$ & $0.53[0.31,0.92]$ \\
\hline Mease 2009 & 49/441 & 34/223 & $=$ & $37.9 \%$ & $0.73[0.49,1.09]$ \\
\hline Vitton 2004 (1) & 6/97 & $5 / 28$ & 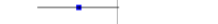 & $6.5 \%$ & $0.35[0.11,1.05]$ \\
\hline Total $(95 \% \mathrm{CI})$ & 1364 & 1098 & - & $100.0 \%$ & $0.66[0.51,0.87]$ \\
\hline \multirow{2}{*}{\multicolumn{6}{|c|}{$\begin{array}{l}\text { Total events: } 98 \text { (Milinacipran), } 106 \text { (Placebo) } \\
\text { Heterogeneity. Chi' }=2.67, \mathrm{df}=3(\mathrm{P}=0.45) ; \mathrm{I}^{2}=0.0 \%\end{array}$}} \\
\hline \multirow{2}{*}{\multicolumn{6}{|c|}{ Test for overall effect: $Z=3.01$ ( $P=0.0026$ ) }} \\
\hline & & & & & \\
\hline \multicolumn{6}{|c|}{ Test for subgroup differences: Not applicable } \\
\hline & & & 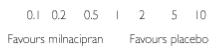 & & \\
\hline \multicolumn{6}{|c|}{ (1) $2 \times 100 \mathrm{mg}$ and I $\times 200 \mathrm{mg}$ combined } \\
\hline
\end{tabular}

\section{Analysis 2.10. Comparison 2 Milnacipran 200 mg/day versus placebo, Outcome 10 Adverse event withdrawals}

Review: Milnacipran for neuropathic pain and fibromyalgia in adults

Comparison: 2 Milnacipran $200 \mathrm{mg} /$ day versus placebo

Outcome: 10 Adverse event withdrawals

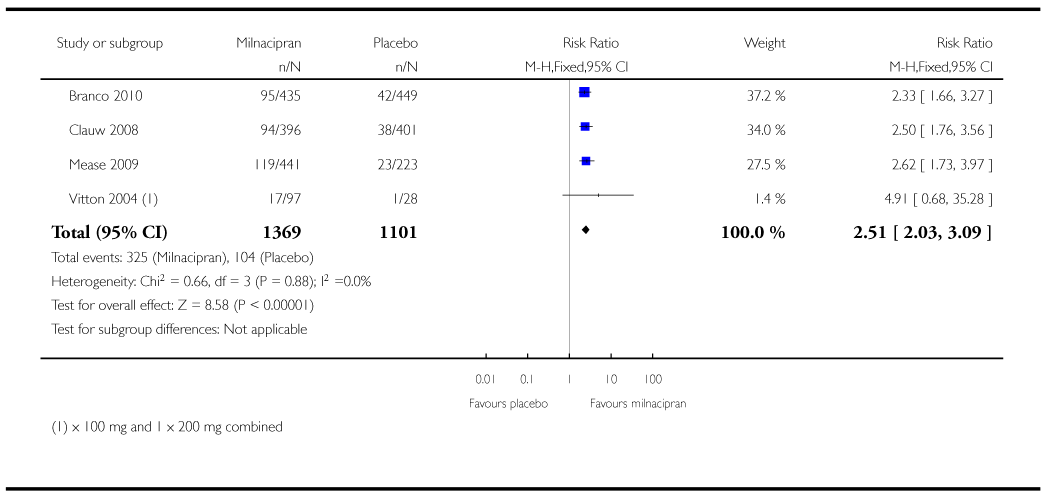

\section{HISTORY}

Protocol first published: Issue 1, 2010 
Review first published: Issue 3, 2012

\section{DIFFERENCES BETWEEN PROTOCOL AND REVIEW}

We have included analyses of two composite efficacy outcomes that were not prespecified in the protocol. We chose to do this because they more closely reflect what is desirable in clinical practice (what patients want), and because they were calculated using baseline observation carried forward, without imputation for missing data, which reflects the situation in clinical practice (if you cannot take the medication you cannot get any benefit from it).

\section{References to studies included in this review}

* Indicates the major publication for the study

Arnold 2010 \{published data only\} . Arnold LM, Gendreau RM, Palmer RH, Gendreau JF, Wang Y. Efficacy and safety of milnacipran $100 \mathrm{mg} /$ day in patients with fibromyalgia. Arthritis and Rheumatism. 2010; 62(9):2745-56. [PubMed: 20496365]

Branco 2010 \{published data only\} . Branco JC, Zachrisson O, Perrot S, Mainguy Y. A European multicenter randomized double-blind placebo-controlled monotherapy clinical trial of milnacipran in treatment of fibromyalgia. Journal of Rheumatology. 2010; 37(4):851-9. [PubMed: 20156949]

Clauw 2008 \{published data only\} . Clauw DJ, Mease P, Palmer RH, Gendreau RM, Wang Y. Milnacipran for the treatment of fibromyalgia in adults: a 15-week, multicenter, randomized, double-blind, placebo-controlled, multiple-dose clinical trial. Clinical Therapeutics. 2008; 30(11):1988-2004. [PubMed: 19108787]

Mease 2009 \{published data only\} . Mease PJ, Clauw DJ, Gendreau RM, Rao SG, Kranzler J, Chen $\mathrm{W}$, et al. The efficacy and safety or milnacipran for treatment of fibromyalgia. A randomized, double-blind, placebo-controlled trial. Journal of Rheumatology. 2009; 36(2):398_409. [PubMed: 19132781]

Vitton 2004 \{published data only\} . Gendreau RM, Thorn MD, Gendreau JF, Kranzler JD, Ribeiro $\mathrm{S}$, Gracely RH, et al. Efficacy of milnacipran in patients with fibromyalgia. Journal of Rheumatology. 2005; 32:1975-85. [PubMed: 16206355] Vitton O, Gendreau M, Gendreau J, Kranzler J, Rao SG. A double-blind placebo-controlled trial of milnacipran in the treatment of fibromyalgia. Human Psychopharmacology. 2004; 19:S27-S35. [PubMed: 15378666]

\section{References to studies excluded from this review}

Branco 2011 \{published data only\} . Branco JC, Cherin P, Montagne A, Bouroubi A, on behalf of the Multinational Coordinator Study Group. Longterm therapeutic response to milnacipran treatment for fibromyalgia. A European 1-year extension study following a 3-month study. Journal of Rheumatology. 2011; 38(7):1403-12. [DOI: 10.3899/jrheum.101025]. [PubMed: 21459941]

Goldenberg 2010 \{published data only\} . Goldenberg DL, Clauw DJ, Palmer RH, Mease P, Chen W, Gendreau RM. Durability of therapeutic response to milnacipran treatment for fibromyalgia. Results of a randomized, double-blind, monotherapy 6-month extension study. Pain Medicine. 2010; 11(2):180-94. [PubMed: 20002596]

NCT00797797 \{unpublished data only\} . [accessed 12 August 2011] A multicenter, randomized, open-label, controlled study to evaluate the safety, tolerability, and efficacy of milnacipran when added to pregabalin in the treatment of fibromyalgia. 2011. http://clinicaltrials.gov/ct2/show/ NCT00797797?term=milnacipran\&rank $=18$ 


\section{References to ongoing studies}

NCT01225068 \{published data only\} . [accessed 12 August 2011] An exploratory randomized placebo controlled trial of milnacipran in patients with chronic neuropathic low back pain. http:// clinicaltrials.gov/ct2/show/NCT01225068?term=milnacipran\&rank=24

NCT01288937 \{published data only\} . [accessed 12 August 2011] A placebo controlled, randomized, double blind trial of milnacipran for the treatment of idiopathic neuropathy pain. http://clinicaltrials.gov/ct2/show/NCT00797797?term=milnacipran\&rank=18

\section{Additional references}

Dworkin 2008 . Dworkin RH, Turk DC, Wyrwich KW, Beaton D, Cleeland CS, Farrar JT, et al. Interpreting the clinical importance of treatment outcomes in chronic pain clinical trials: IMMPACT recommendations. Journal of Pain. 2008; 9(2):105-21. [DOI: 10.1016/j.jpain. 2007.09.005]. [PubMed: 18055266]

Gustorff 2008 . Gustorff B, Dorner T, Likar R, Grisold W, Lawrence K, Schwarz F, et al. Prevalence of self-reported neuropathic pain and impact on quality of life: a prospective representative survey. Acta Anaesthesiologica Scandinavica. 2008; 52(1):132-6. [PubMed: 17976220]

Hall 2006 . Hall GC, Carroll D, Parry D, McQuay HJ. Epidemiology and treatment of neuropathic pain: the UK primary care perspective. Pain. 2006; 122(1-2):156-62. [DOI: 10.1016/j.pain. 2006.01.030]. [PubMed: 16545908]

Hauser 2010 . Häuser W, Petzke F, Sommer C. Comparative efficacy and harms of duloxetine, milnacipran, and pregabalin in fibromyalgia syndrome. Journal of Pain. 2010; 11(6):505-21. [PubMed: 20418173]

Hauser 2011 . Häuser W, Petzke F, Üçeyler N, Sommer C. Comparative efficacy and acceptability of amitriptyline, duloxetine and milnacipran in fibromyalgia syndrome: a systematic review with meta-analysis. Rheumatology (Oxford). 2011; 50(3):532-43. [DOI: 10.1093/rheumatology/ keq354]. [PubMed: 21078630]

Hoffman 2010 . Hoffman DL, Sadosky A, Dukes EM, Alvir J. How do changes in pain severity levels correspond to changes in health status and function in patients with painful diabetic peripheral neuropathy? Pain. 2010; 149(2):194-201. [DOI: 10.1016/j.pain.2009.09.017]. [PubMed: 20303665]

Jensen 2011 . Jensen TS, Baron R, Haanpää M, Kalso E, Loeser JD, Rice AS, et al. A new definition of neuropathic pain. Pain. 2011; 152(10):2204-5. [DOI: 10.1016/j.pain.2011.06.017]. [PubMed: 21764514]

Kjaergard 2001 . Kjaergard LL, Villumsen J, Gluud C. Reported methodologic quality and discrepancies between large and small randomized trials in meta-analyses. Annals of Internal Medicine. 2001; 135(11):982-9. [PubMed: 11730399]

Kyle 2010 . Kyle JA, Dugan BD, Testerman KK. Milnacipran for treatment of fibromyalgia. Annals of Pharmacotherapy. 2010; 44(9):1422-9. [DOI: 10.1345/aph.1P218]. [PubMed: 20716692]

L‘Abbé 1987 . L'Abbé KA, Detsky AS, O’Rourke K. Meta-analysis in clinical research. Annals of Internal Medicine. 1987; 107:224-33. [PubMed: 3300460]

Lee 2010 . Lee YC, Chen PP. A review of SSRIs and SNRIs in neuropathic pain. Expert Opinion in Pharmacotherapy. 2010; 11(17):2813-25.

McQuay 1998 . McQuay, H.; Moore, R. An Evidence-based Resource for Pain Relief. Oxford University Press; Oxford: 1998. [ISBN: 0-19-263048-2]

McQuay 2007 . McQuay, HJ.; Smith, LA.; Moore, RA. Chronic pain. In: Stevens, A.; Raferty, J.; Mant, J.; Simpson, S., editors. Health Care Needs Assessment. Radcliffe Publishing Ltd; Oxford: 2007. p. 519-600.[ISBN: 978-1-84619-063-6]

Moore 1998 . Moore RA, Gavaghan D, Tramèr MR, Collins SL, McQuay HJ. Size is everything large amounts of information are needed to overcome random effects in estimating direction and magnitude of treatment effects. Pain. 1998; 78(3):209-16. [DOI: 10.1016/

S0304-3959(98)00140-7]. [PubMed: 9870574] 
Moore 2005 . Moore RA, Edwards JE, McQuay HJ. Acute pain: individual patient meta-analysis shows the impact of different ways of analysing and presenting results. Pain. 2005; 116(3):32231. [DOI: 10.1016/j.pain.2005.05.001]. [PubMed: 15979792]

Moore 2008 . Moore, RA.; Barden, J.; Derry, S.; McQuay, HJ. Managing potential publication bias. In: McQuay, HJ.; Kalso, E.; Moore, RA., editors. Systematic Reviews in Pain Research: Methodology Refined. IASP Press; Seattle: 2008. p. 15-24.[ISBN: 978-0-931092-69-5]

Moore 2009 . Moore RA, Straube S, Wiffen PJ, Derry S, McQuay HJ. Pregabalin for acute and chronic pain in adults. Cochrane Database of Systematic Reviews. 2009; (Issue 3) [DOI: 10.1002/14651858.CD007076].

Moore 2010a . Moore RA, Eccleston C, Derry S, Wiffen P, Bell RF, Straube S, et al. ACTINPAIN Writing Group of the IASP Special Interest Group on Systematic Reviews in Pain Relief, Cochrane Pain, Palliative and Supportive Care Systematic Review Group Editors. "Evidence" in chronic pain--establishing best practice in the reporting of systematic reviews. Pain. 2010; 150(3):386-9. [DOI: 10.1016/j.pain.2010.05.011]. [PubMed: 20627575]

Moore 2010b . Moore RA, Moore OA, Derry S, Peloso PM, Gammaitoni AR, Wang H. Responder analysis for pain relief and numbers needed to treat in a meta-analysis of etoricoxib osteoarthritis trials: bridging a gap between clinical trials and clinical practice. Annals of the Rheumatic Diseases. 2010; 69(2):374-9. [DOI: 10.1136/ard.2009.107805]. [PubMed: 19364730]

Moore 2010c . Moore RA, Straube S, Paine J, Phillips CJ, Derry S, McQuay HJ. Fibromyalgia: moderate and substantial pain intensity reduction predicts improvement in other outcomes and substantial quality of life gain. Pain. 2010; 149(3):260-4. [DOI: 10.1016/j.pain.2010.02.039].

Moore 2011 . Moore RA, Straube S, Eccleston C, Derry S, Aldington D, Wiffen P, et al. Estimate at your peril: imputation methods for patient withdrawal can bias efficacy outcomes in chronic pain trials using responder analyses. Pain. 2011 [Epub November 3]. [DOI: 10.1016/j.pain. 2011.10.004].

Nuesch 2010 . Nüesch E, Trelle S, Reichenbach S, Rutjes AW, Tschannen B, Altman DG, et al. Small study effects in meta-analyses of osteoarthritis trials: meta-epidemiological study. BMJ. 2010; 341:c3515. [DOI: 10.1136/bmj.c3515]. [PubMed: 20639294]

Ormseth 2010 . Ormseth MJ, Eyler AE, Hammonds CL, Boomershine CS. Milnacipran for the management of fibromyalgia syndrome. Journal of Pain Research. 2010; 1(3):15-24. [PubMed: 21197306]

Recla 2010 . Recla JM. New and emerging therapeutic agents for the treatment of fibromyalgia: an update. Journal of Pain Research. 2010; 22(3):89-103. [PubMed: 21197313]

RevMan 2011 . The Nordic Cochrane Centre. The Cochrane Collaboration. Review Manager (RevMan). 5.1. The Nordic Cochrane Centre, The Cochrane Collaboration; Copenhagen: 2011.

Roskell 2011 . Roskell NS, Beard SM, Zhao Y, Le TK. A meta-analysis of pain response in the treatment of fibromyalgia. Pain Practice. 2011; 11(6):516-27. [DOI: 10.1111/j. 1533-2500.2010.00441.x]. [PubMed: 21199320]

Saarto 2007 . Saarto T, Wiffen PJ. Antidepressants for neuropathic pain. Cochrane Database of Systematic Reviews. 2007; (Issue 4) [DOI: 10.1002/14651858.CD005454.pub2].

Straube 2008 . Straube S, Derry S, McQuay HJ, Moore RA. Enriched enrollment: definition and effects of enrichment and dose in trials of pregabalin and gabapentin in neuropathic pain. A systematic review. British Journal Clinical Pharmacology. 2008; 66(2):266-75. [DOI: 10.1111/j. 1365-2125.2008.03200.x].

Straube 2011 . Straube S, Moore RA, Paine J, Derry S, Phillips CJ, Hallier E, et al. Interference with work in fibromyalgia: effect of treatment with pregabalin and relation to pain response. BMC Musculoskeletal Disorders. 2011; 12:125. [DOI: 10.1186/1471-2474-12-125]. [PubMed: 21639874]

Sultan 2008 . Sultan A, Gaskell H, Derry S, Moore RA. Duloxetine for painful diabetic neuropathy and fibromyalgia pain: systematic review of randomised trials. BMC Neurology. 2008; 8:29. [DOI: 10.1186/1471-2377-8-29]. [PubMed: 18673529]

Suzuki 2004 . Suzuki R, Rygh LJ, Dickenson AH. Bad news from the brain: descending 5-HT pathways that control spinal pain processing. Trends in the Pharmacological Sciences. 2004; 2512:613-7. 
Wolfe 1990 . Wolfe F, Smythe HA, Yunus MB, Bennett RM, Bombardier C, Goldenberg DL, et al. The American College of Rheumatology 1990 Criteria for the Classification of Fibromyalgia. Report of the Multicenter Criteria Committee. Arthritis and Rheumatism. 1990; 33:160-72. [PubMed: 2306288]

Wolfe 2010 . Wolfe F, Clauw DJ, Fitzcharles MA, Goldenberg DL, Katz RS, Mease P, et al. The American College of Rheumatology preliminary diagnostic criteria for fibromyalgia and measurement of symptom severity. Arthritis Care and Research. 2010; 62(5):600-10. [DOI: 10.1002/acr.20140]. [PubMed: 20461783] 


\section{PLAIN LANGUAGE SUMMARY}

\section{Milnacipran for chronic neuropathic pain and fibromyalgia in adults}

The aim of this review was to assess how effective milnacipran is for treating chronic neuropathic pain or fibromyalgia. We identified no studies using milnacipran in neuropathic pain, but five studies in fibromyalgia satisfied the inclusion criteria. Fibromyalgia is a complex pain syndrome, defined as widespread pain for longer than three months; the original diagnostic criteria involved pain on palpation at 11 or more of a number of specified tender points (Wolfe 1990), with later criteria including both widespread pain and symptom severity (Wolfe 2010). The studies included over 4000 participants treated with milnacipran $100 \mathrm{mg}$ or $200 \mathrm{mg}$, or placebo, for eight to 24 weeks at the target dose. Overall study quality was good, although the method of analysis for our primary outcomes could overestimate treatment effect.

Milnacipran at either dose provided moderate pain relief (at least 30\% reduction in pain intensity) to $10 \%$ more participants than did placebo. This relatively modest effect may be clinically important in this difficult to treat condition. Adverse events were reported by the majority of participants in all groups, but were more common with milnacipran than placebo, with nausea and constipation showing the greatest differences. Serious adverse events were uncommon (less than $2 \%$ ) and did not differ between treatment groups. Withdrawals due to adverse events were also more common with milnacipran than placebo, and were more common with $200 \mathrm{mg}$ than $100 \mathrm{mg}$, while withdrawals due to lack of efficacy were less common with milnacipran, with no difference between doses.

Milnacipran has shown modest effects in a minority of participants with fibromyalgia, and several technical issues indicate that even this modest effect may overstate effectiveness in clinical practice The drug may be a useful option if first-line treatments fail. 


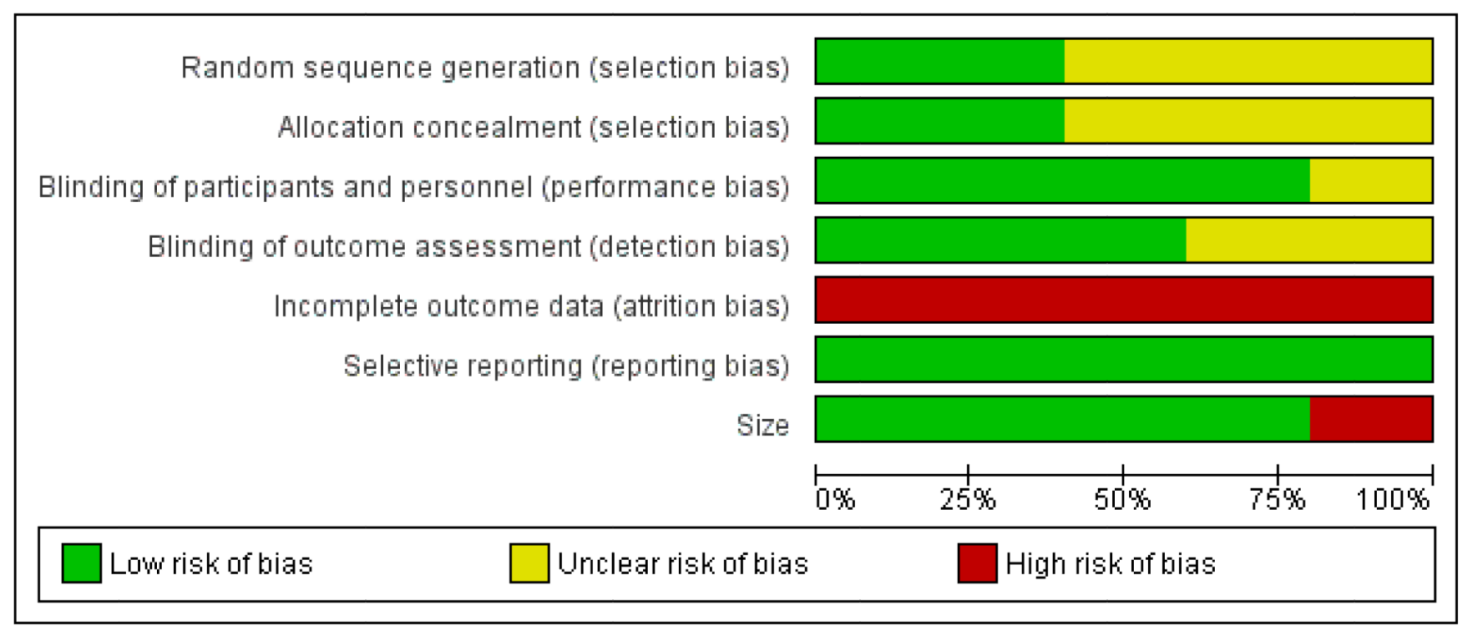

Figure 1.

'Risk of bias' graph: review authors' judgements about each risk of bias item presented as percentages across all included studies. 


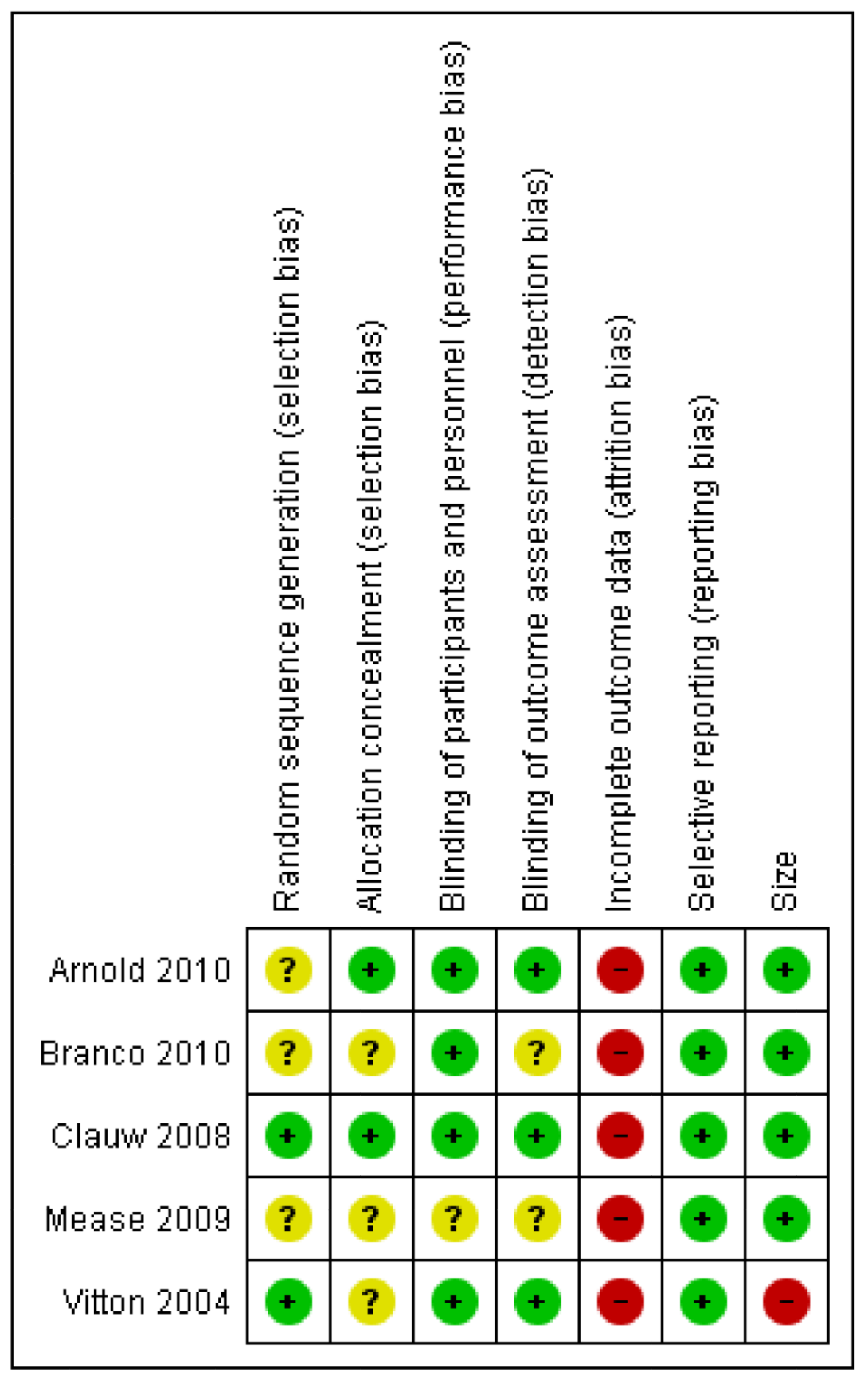

Figure 2.

'Risk of bias' summary: review authors' judgements about each risk of bias item for each included study. 


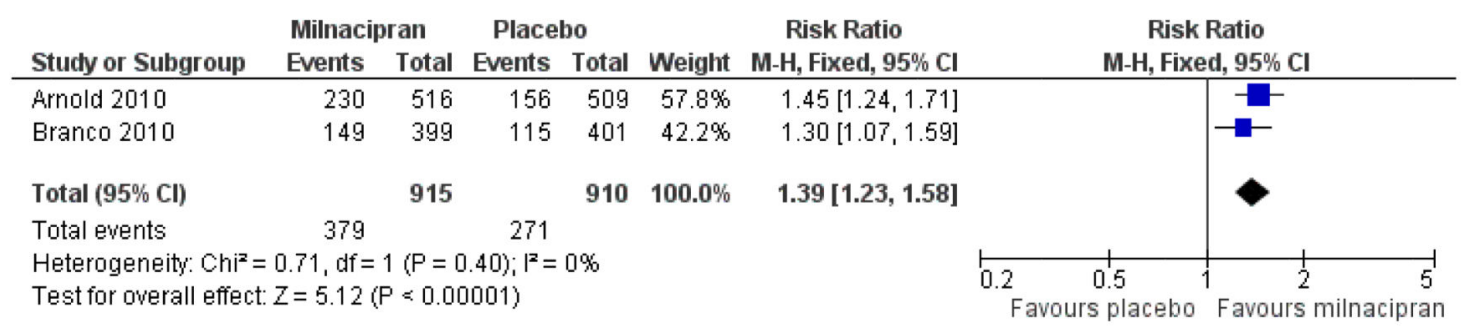

Figure 3.

Forest plot of comparison: 1 Milnacipran $100 \mathrm{mg} /$ day versus placebo, outcome: 1.1 At least $30 \%$ pain relief. 


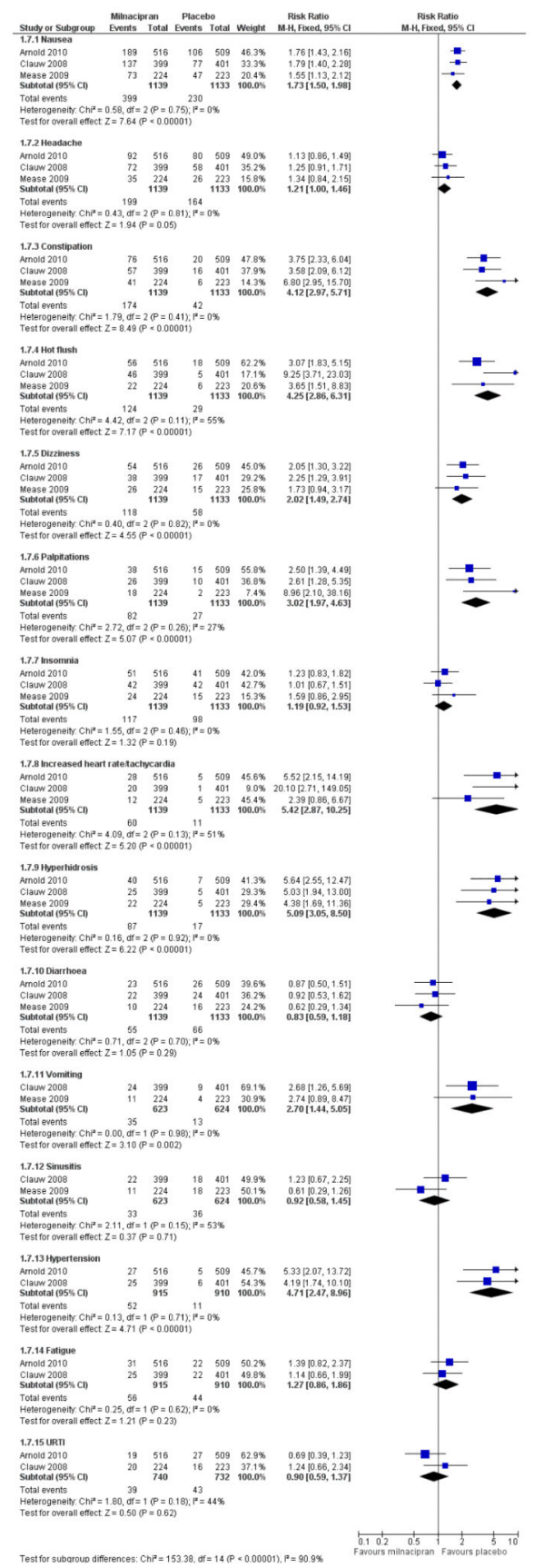

Figure 4.

Forest plot of comparison: 1 Milnacipran $100 \mathrm{mg} /$ day versus placebo, outcome: 1.7 Individual adverse events. 